\title{
Antiparasitic Activities of Acridone Alkaloids from Swinglea glutinosa (Bl.) Merr.
}

\author{
Djalma A. P. dos Santos, ${ }^{a}$ Paulo C. Vieira, ${ }^{*}, a$ M. Fátima das G. F. da Silva, ${ }^{a}$ \\ João B. Fernandes, ${ }^{a}$ Lauren Rattray ${ }^{b}$ and Simon L. Croft ${ }^{b}$
}

\author{
${ }^{a}$ Departamento de Química, Universidade Federal de São Carlos, CP 676, 13565-905 São Carlos-SP, Brazil \\ ${ }^{b}$ Department of Infectious and Tropical Diseases, London School of Hygiene \& Tropical Medicine, \\ London, WC1E 7HT, UK
}

\begin{abstract}
Onze alcalóides acridônicos isolados de Swinglea glutinosa (B1.) Merr. foram avaliados para suas atividades in vitro contra linhagens de Plasmodium falciparum sensíveis a cloroquina 3D7, Trypanosoma brucei rhodesiense STIB9000 e Leishmania donovani L82. Ensaios com células KB foram também executados com o objetivo de se determinar o grau de toxicidade das substâncias ativas contra os parasitas. Nove dos compostos apresentaram $\mathrm{IC}_{50}$ entre 0,3 e 11,6 $\mu \mathrm{M}$ contra $P$. falciparum. Em contraste, um pequeno número de compostos mostrou atividade significativa contra T. brucei rhodesiense e nenhum apresentou atividade contra L. donovani. Entre os alcalóides três tiveram $\mathrm{IC}_{50}<1,0 \mu \mathrm{M}$ contra $P$. falciparum, enquanto que contra $T$. $b$. rhodesiense cinco mostraram $\mathrm{IC}_{50}<10 \mu \mathrm{M}$. A caracterização dos alcalóides, 1,3,5-triidróxi-4-metóxi-10-metil-2,8bis(3-metilbut-2-enil)acridin-9(10H)-ona (1), 2,3-diidro-4,9-diidróxi-2-(2-hidróxipropan-2-il)11-metóxi-10-metilfuro[3,2-b]acridin-5(10H)-ona (2) e 3,4-diidro-3,5,8-triidróxi-6-metóxi-2,2,7trimetil-2H-pirano[2,3-a] acridin-12(7H)-ona (3), é aqui discutida. Discute-se também a relação estrutura-atividade para todos os compostos ensaiados. O isolamento e dados espectrais para os alcalóides 1-3 estão sendo aqui descritos pela primeira vez, embora em trabalho anterior tenham sido relatadas as suas atividades citotóxicas.
\end{abstract}

Eleven acridone alkaloids isolated from Swinglea glutinosa (B1.) Merr. were examined for in vitro activity against chloroquine-sensitive Plasmodium falciparum 3D7, Trypanosoma brucei rhodesiense STIB900 and Leishmania donovani L82. An assay with KB cells was developed in order to compare in vitro toxicity of alkaloids with the selective action on the parasites. Nine of the compounds had $\mathrm{IC}_{50}$ values ranging from 0.3 to $11.6 \mu \mathrm{M}$ against $P$. falciparum. In contrast, a small number of compounds showed significant activity against $T$. brucei rhodesiense and none had activity against $L$. donovani. Among the alkaloids three had $\mathrm{IC}_{50}<1.0 \mu \mathrm{M}$ against $P$. falciparum, whereas against $T$. $b$. rhodesiense five had $\mathrm{IC}_{50}<10 \mu \mathrm{M}$. The characterization of the acridone alkaloids, 1,3,5-trihydroxy-4-methoxy-10-methyl-2,8-bis(3-methylbut-2-enyl)acridin-9(10H)-one (1), 2,3-dihydro-4,9-dihydroxy-2-(2-hydroxypropan-2-yl)-11-methoxy-10-methylfuro[3,2-b] acridin-5(10H)-one (2) and 3,4-dihydro-3,5,8-trihydroxy-6-methoxy-2,2,7-trimethyl-2Hpyrano[2,3-a] acridin-12(7H)-one (3), is discussed, as well as the structure-activity relationship of all compounds assayed. Isolation and spectral data of alkaloids 1-3 are described for the first time although their citotoxicities to cancer cells have been described before.

Keywords: antiparasitic acridone alkaloids, malaria, Swinglea glutinosa, Rutaceae

\section{Introduction}

Parasitic protozoa are the causative agents of human and livestock diseases infecting hundreds of millions of people every year and are collectively one of most important causes of human misery. ${ }^{1}$ Human African trypanosomiasis (HAT), or sleeping sickness, malaria, Chagas' disease and

\footnotetext{
*e-mail: paulo@dq.ufscar.br
}

leishmaniasis are major health problems in many countries. HAT promoted by Trypanosoma brucei rhodesiense and T. b. gambiense is endemic in over 30 African countries threatening over 60 million people. HAT has reached epidemic proportions in some countries, such as Angola, southern Sudan, Uganda and the Democratic Republic of Congo. ${ }^{2,3}$ Malaria has re-emerged as a major public health problem over the past three decades mainly because of the development of worldwide resistance of Plasmodium 
falciparum to chloroquine, a drug which formed the basis for cheap and effective treatment and for prophylaxis of this disease. ${ }^{4}$ Each year, approximately 300 to 500 million malaria infections lead to over one million deaths. In many endemic countries, malaria is responsible for economic stagnation, lowering the annual economic growth in some regions by up to $1.5 \%{ }^{5,6}$ Leishmaniasis is a disease caused by protozoa of the genus Leishmania. According to WHO 88 countries are affected, with 350 million people at risk. $90 \%$ of cases of visceral leishmaniasis occur in India, Sudan, Bangladesh and Brazil. ${ }^{7}$ Present chemotherapy for these diseases is inadequate or toxic, or becoming ineffective due to an increase in resistance. ${ }^{8}$

The family Rutaceae contains many secondary metabolites such as alkaloids, flavonoids, coumarins, limonoids and lignans with a large spectrum of biological activities. ${ }^{9}$ Studies showed that acridone alkaloids are compounds with promising activity against $P$. falciparum, ${ }^{10,11}$ and also have antiviral ${ }^{12}$ and antiproliferative effects on cancer cell lines. ${ }^{13,14}$ The Asian genera Citrus and Swinglea are members of the Rutaceae and are included in the subfamily Aurantioideae. Citrus species have been investigated and characterized by possessing acridone alkaloids. These data stimulated an investigation of Swinglea glutinosa (B1.) Merr. in a search for lead acridones.

From the $\mathrm{MeOH}$ extract of the stem bark of $S$. glutinosa three new acridone alkaloids were identified: 1,3,5-trihydroxy-4-methoxy-10-methyl-2,8-bis(3methylbut-2-enyl)acridin-9(10H)-one (1), 2,3-dihydro4,9-dihydroxy-2-(2-hydroxypropan-2-yl)-11-methoxy10-methylfuro[3,2-b]acridin-5(10H)-one (2) and 3,4-dihydro-3,5,8-trihydroxy-6-methoxy-2,2,7-trimethyl$2 H$-pyrano[2,3-a]acridin-12(7H)-one (3). In addition, eight known alkaloids were characterized by the analysis of their NMR spectra and compared with reference data: 1,3,5-trihydroxy-2,8-bis(3-methylbut-2-enyl)-10-methyl9-acridone (4), ${ }^{10}$ glycocitrine-IV (5), ${ }^{15}$ citrusinine-II (6), ${ }^{16}$ citrusinine-I (7), ${ }^{17}$ citibrasine (8), ${ }^{16}$-hydroxynoracronycine (9), ${ }^{18}$ pyranofoline (10) ${ }^{19}$ and bis-5-hydroxynoracronycine $(\mathbf{1 1})^{20}$. These alkaloids were tested in vitro against chloroquine-sensitive P. falciparum 3D7, T. b. rhodesiense STIB900, L. donovani L82 and their toxicity effects were also evaluated on KB cells.<smiles>[R]c1c([R])c([R])c2c(c1O)c(=O)c1c([Z])ccc(O)c1n2C</smiles>
$1 \quad R^{1}=\left.\overbrace{2^{\prime}}^{4^{4^{\prime}}}\right|_{5^{\prime}} ^{3^{\prime}}$
$\mathrm{R}^{2}=\mathrm{OH} \quad \mathrm{R}^{3}=\mathrm{OCH}_{3}$
$4 \mathrm{R}^{1}=\mathrm{R}^{2}=\mathrm{OH} \quad \mathrm{R}^{3}=\mathrm{H}$
$\mathrm{R}^{4}=\overbrace{2^{\prime \prime}}^{3^{4 "}}$
$\mathrm{R}^{1}=>$
$\mathrm{R}^{2}=\mathrm{OH} \quad \mathrm{R}^{3}=\mathrm{OCH}_{3} \quad \mathrm{R}^{4}=\mathrm{H}$
$6 \quad \mathrm{R}^{1}=\mathrm{H}$
$\mathrm{R}^{2}=\mathrm{OH} \quad \mathrm{R}^{3}=\mathrm{OCH}_{3} \quad \mathrm{R}^{4}=\mathrm{H}$
$7 \quad \mathrm{R}^{1}=\mathrm{H}$
$\mathrm{R}^{2}=\mathrm{R}^{3}=\mathrm{OCH}_{3}$
$\mathrm{R}^{4}=\mathrm{H}$
$8 \quad \mathrm{R}^{1}=\mathrm{R}^{2}=\mathrm{R}^{3}=\mathrm{OCH}_{3} \quad \mathrm{R}^{4}=\mathrm{H}$

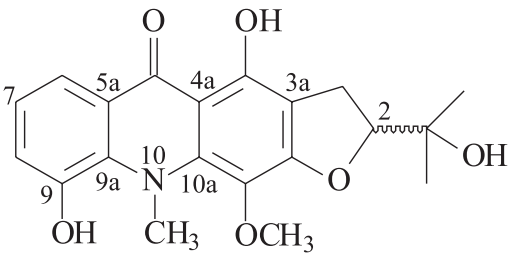

2<smiles>Cn1c2c(cc(O)c3c(=O)c4cccc(O)c4c1=3)OC(C)(C)C=C2</smiles><smiles>COc1c2c(c(O)c3c(=O)c4cccc(O)c4n(C)c13)C=CC(C)(C)O2</smiles>

10<smiles>COc1c(O)c2c(c3c(=O)c4cccc(O)c4n(C)c13)OC(C)(C)[C@H](O)C2</smiles>

3<smiles></smiles> 


\section{Results and Discussion}

Compound 1 was isolated as an amorphous powder, the molecular formula was determined as $\mathrm{C}_{25} \mathrm{H}_{29} \mathrm{NO}_{5}$ by HRESIMS, showing an $[\mathrm{M}+\mathrm{H}]^{+}$peak at $\mathrm{m} / z$ 424.2124. The UV absorptions bands at $\lambda_{\text {max }} / \mathrm{nm}: 222,265,285,332$ and $410 \mathrm{~nm}$, IR absorptions at $v_{\max } / \mathrm{cm}^{-1}: 3500$ and $1625 \mathrm{~cm}$ and the characteristic signal of a hydrogen-bonded hydroxyl proton at $\delta 14.42$ in the ${ }^{1} \mathrm{H}$ NMR spectra, exchangeable with $\mathrm{D}_{2} \mathrm{O}$, suggested the presence of a hydroxyl group. These data together with analyses of the ${ }^{13} \mathrm{C}$ NMR spectrum, suggested that compound $\mathbf{1}$ had a 1-hydroxy-9-acridone framework. ${ }^{16-22}$

The ${ }^{1} \mathrm{H}$ NMR spectrum of the compound 1 showed two AB type aromatic protons at $\delta 7.17(1 \mathrm{H}, \mathrm{d}, J 8.0 \mathrm{~Hz}$, $\mathrm{H}-6)$ and $6.96(1 \mathrm{H}, \mathrm{d}, J 8.0 \mathrm{~Hz}, \mathrm{H}-7)$, one $N$-methyl group at $\delta 3.74$ and one $O$-methyl group at $\delta 3.76$. Also signals of two trisubstituted double bonds at $\delta 5.41(1 \mathrm{H}, \mathrm{m}, \mathrm{H}-2 ")$, $5.31\left(1 \mathrm{H}, \mathrm{m}, \mathrm{H}-2^{\prime}\right)$, two methylene protons at $\delta 4.01(2 \mathrm{H}$, d, $J 7.0 \mathrm{~Hz}, \mathrm{H}-1$ '), $3.40(2 \mathrm{H}, \mathrm{d}, J 7.0 \mathrm{~Hz}, \mathrm{H}-1$ '), the former protons being deshielded by the 9-carbonyl group, and four vinyl methyl groups $[\delta 1.80(3 \mathrm{H}, \mathrm{d}, J 0.9 \mathrm{~Hz}, \mathrm{H}-4$ ' $E), 1.65$ $(3 \mathrm{H}, \mathrm{d}, J 1.0 \mathrm{~Hz}, \mathrm{H}-5$ ' Z), 1.74 (3H,d, J 0.9Hz, H-4” E), 1.69 $(3 \mathrm{H}, \mathrm{d}, J 1.0 \mathrm{~Hz}, \mathrm{H}-5$ " $Z)]$ were observed, which suggested the presence of two prenyl groups (3-methylbut-2-enyl). Their positions were confirmed at $\mathrm{C}-2$ and $\mathrm{C}-8$ by $\mathrm{HMBC}$.

The position of a prenyl group at $\mathrm{C}-2$ was confirmed by the correlation of the methylene protons at $\delta 3.40\left(\mathrm{H}-1^{\prime}\right)$ with C-1 $(\delta 158.1), \mathrm{C}-2(\delta$ 109.4), C-3 $(\delta$ 156.1), C-2' $(\delta$ 123.6) and $\mathrm{C}-3^{\prime}(\delta 131.4)$ in the HMBC spectrum. In addition, the correlation of $1-\mathrm{OH}$ at $\delta 14.42$ with C-1 and C-9a $(\delta$ 107.6) confirmed that the first prenyl group was attached to C-2. The position of the second prenyl group was confirmed by the correlation of the deshielded methylene protons at $\delta 4.01$ $(\mathrm{H}-1 ")$ with C-7 ( $\delta 125.4), \mathrm{C}-8(\delta 135.0), \mathrm{C}-2 "(\delta 125.4)$ and $\mathrm{C}-3$ " $(\delta 131.2)$, confirming that the second prenyl group was attached to C-8. The $N$-methyl protons showed correlation with C-4a and C-5a at $\delta 140.2$ and 139.4, respectively. The $O$-methyl protons showed correlation with C-4 at $\delta 128.8$. This value is consistent with the acridone possessing an $O$-methyl group at C-4. ${ }^{17,23}$ Based on these data, the structure of 1 was characterized as 1,3,5-trihydroxy-4-methoxy-10methyl-2,8-bis(3-methylbut-2-enyl)acridin-9(10H)-one. Table 1 shows the data of ${ }^{1} \mathrm{H},{ }^{13} \mathrm{C}$ NMR and correlations observed in the HMBC experiment.

Compound 2 was isolated as an amorphous powder, the molecular formula $\mathrm{C}_{20} \mathrm{H}_{21} \mathrm{NO}_{6}$ was determined on the basis of HRESIMS, exhibiting an $[\mathrm{M}+\mathrm{H}]^{+}$peak at $m / 2372.1447$. The UV and IR spectra were identical to those of $\mathbf{1}$, however some differences were observed in the ${ }^{1} \mathrm{H}$ and ${ }^{13} \mathrm{C}$ NMR. In the ${ }^{1} \mathrm{H}$ NMR spectrum, the characteristic signal of a
Table 1. ${ }^{1} \mathrm{H}$ and ${ }^{13} \mathrm{C}$ NMR and HMBC data for compound $\mathbf{1}$ (acetone- $d_{6}$ )

\begin{tabular}{|c|c|c|c|}
\hline Position & ${ }^{13} \mathrm{C}^{\mathrm{a}} \delta$ & ${ }^{1} \mathrm{H}^{\mathrm{b}} \delta$ (mult., $J$ in $\mathrm{Hz}$ ) & $\mathrm{HMBC}^{\mathrm{b}}(\mathrm{H}-\mathrm{C})$ \\
\hline 1 & 158.1 & & \\
\hline $1-\mathrm{OH}$ & & $14.42(\mathrm{~s})$ & $\mathrm{C}-1, \mathrm{C}-2$ \\
\hline 2 & 109.4 & & \\
\hline 3 & 156.1 & & \\
\hline 4 & 128.8 & & \\
\hline $4^{\mathrm{a}}$ & 140.2 & & \\
\hline 5 & 147.3 & & \\
\hline $5^{\mathrm{a}}$ & 139.4 & & \\
\hline 6 & 120.0 & $7.17(\mathrm{~d}, 8.0)$ & C-5, C-8, C-5a \\
\hline 7 & 125.4 & $6.96(\mathrm{~d}, 8.0)$ & C-8a, C-1" \\
\hline 8 & 135.0 & & \\
\hline $8 \mathrm{a}$ & 123.6 & & \\
\hline 9 & 185.5 & & \\
\hline $9 \mathrm{a}$ & 107.6 & & \\
\hline $\mathrm{N}-\mathrm{CH}_{3}$ & 45.3 & $3.74(\mathrm{~s})$ & C-4a, C-5a \\
\hline $\mathrm{O}-\mathrm{CH}_{3}$ & 59.8 & $3.76(\mathrm{~s})$ & C-4 \\
\hline 1 , & 22.4 & $3.40(\mathrm{~d}, 7.0)$ & $\mathrm{C}-1, \mathrm{C}-2, \mathrm{C}-3, \mathrm{C}-3^{\prime}, \mathrm{C}-2^{\prime}$ \\
\hline $2^{\prime}$ & 123.6 & $5.31(\mathrm{~m})$ & C-4', C-5' \\
\hline $3^{\prime}$ & 131.4 & & \\
\hline $4^{\prime}$ & 25.9 & $1.65(\mathrm{~d}, 1.0)$ & $\mathrm{C}-2^{\prime}, \mathrm{C}-3^{\prime}, \mathrm{C}-5^{\prime}$ \\
\hline 5 & 17.8 & $1.80(\mathrm{~d}, 0.9)$ & $\mathrm{C}-2^{\prime}, \mathrm{C}-4^{\prime}, \mathrm{C}-3^{\prime}$ \\
\hline $1 "$ & 34.3 & $4.01(\mathrm{~d}, 7.0)$ & C-7, C-8, C-2", C-3" \\
\hline $2 "$ & 125.4 & $5.41(\mathrm{~m})$ & C-4', C-5"' \\
\hline $3 "$ & 131.2 & & \\
\hline $4 "$ & 25.9 & $1.74(\mathrm{~d}, 0.9)$ & C-2", C-3", C-5" \\
\hline $5 "$ & 18.0 & $1.69(\mathrm{~d}, 1.0)$ & C-2", C-3", C-4" \\
\hline
\end{tabular}

${ }^{\text {a }}$ Recorded at $100 \mathrm{MHz} ;{ }^{b}$ Recorded at $400 \mathrm{MHz}$.

hydrogen-bonded hydroxy proton at $\delta 14.42$, exchangeable with $\mathrm{D}_{2} \mathrm{O}$ suggested the presence of a hydroxyl group. These data suggested that compound $\mathbf{2}$ had a 4-hydroxy5-acridone skeleton. ${ }^{16-22}$

The ${ }^{1} \mathrm{H}$ NMR spectrum of 2 showed an ABX type aromatic spin system at $\delta 7.15(1 \mathrm{H}, \mathrm{t}, J 7.8 \mathrm{~Hz}, \mathrm{H}-7), 7.29$ $(1 \mathrm{H}, \mathrm{dd}, J 7.8,1.4 \mathrm{~Hz}, \mathrm{H}-8)$ and $7.80(1 \mathrm{H}, \mathrm{dd}, J 7.8,1.4 \mathrm{~Hz}$, $\mathrm{H}-6$ ), this last proton being deshielded by the 5-carbonyl group. The spectrum also showed one $N$-methyl group at $\delta 3.85$ and one $O$-methyl group at $\delta 3.89$. The presence of a hydroxyisopropyldihydrofuran moiety was suggested by an oxymethine proton at $\delta 4.88(1 \mathrm{H}, \mathrm{dd}, J 9.4,7.8 \mathrm{~Hz}, \mathrm{H}-2)$, methylene protons as two dd in an $\mathrm{AB}$ system at $\delta 3.20(1 \mathrm{H}$, $\mathrm{dd}, J 15.5,7.8 \mathrm{~Hz}, \mathrm{H}-3 \mathrm{a})$ and $3.26(1 \mathrm{H}, \mathrm{dd}, J 15.5,9.4 \mathrm{~Hz}$, $\mathrm{H}-3 \mathrm{~b})$, two methyl groups at $\delta 1.33\left(3 \mathrm{H}, \mathrm{s}, \mathrm{H}-2^{\prime}\right)$ and 1.29 $\left(3 \mathrm{H}, \mathrm{s}, \mathrm{H}-3^{\prime}\right)$. The signal at $\delta 93.0$ and 71.5 in the ${ }^{13} \mathrm{C}$ NMR spectrum supported the presence of this substituent in the acridone nucleus. ${ }^{23}$ 
The presence of a linear orientation of the hydroxyisopropyldihydrofuran moiety was confirmed by correlations of the methylene protons at $\delta 3.20(\mathrm{H}-3)$ with C-3a $(\delta 109.4), \mathrm{C}-2(\delta 93.0)$ and C-1' $\delta 71.5$ and the correlations of the 4-OH at $\delta 14.31$ with $\mathrm{C}-4 \mathrm{a}(\delta 108.4)$, $\mathrm{C}-4$ and $\mathrm{C}-3 \mathrm{a}$ in the HMBC spectrum. The spectrum also showed the correlation of the signals of the $N$-methyl protons at $\delta 3.85$ with $\delta 143.5$ and 138.0 assigned to C-11a and C-9a, respectively. The $O$-methyl proton at $\delta 3.89$ showed correlation with $\mathrm{C}-11$ at $\delta$ 126.6. The correlation at $\mathrm{H}-6, \mathrm{H}-7$ and $\mathrm{H}-8$ in the HMBC spectrum allowed the assignments of the carbons C-9, C-9a, C-8, C-7, C-6, $\mathrm{C}-5 \mathrm{a}$ and $\mathrm{C}-5$. Based on the above evidence, compound 2 could be defined as 2,3-dihydro-4,9-dihydroxy-2-(2hydroxypropan-2-yl)-11-methoxy-10-methylfuro[3,2-b] acridin-5(10H)-one. Table 2 shows ${ }^{1} \mathrm{H},{ }^{13} \mathrm{C}$ NMR data for 2 and the correlations observed in the HMBC.

Table 2. ${ }^{1} \mathrm{H}$ and ${ }^{13} \mathrm{C}$ NMR and HMBC data for compound 2 (acetone- $d_{6}$ )

\begin{tabular}{|c|c|c|c|}
\hline Position & ${ }^{13} \mathrm{C}^{\mathrm{a}} \delta$ & ${ }^{1} \mathrm{H}^{\mathrm{b}} \delta$ (mult., $J$ in $\mathrm{Hz}$ ) & $\mathrm{HMBC}^{\mathrm{b}}(\mathrm{H}-\mathrm{C})$ \\
\hline 2 & 93.0 & $4.88 \mathrm{dd}(9.4,7.8)$ & $\begin{array}{l}\mathrm{C}-2^{\prime} / \mathrm{C}-3^{\prime}, \\
\mathrm{C}-1^{\prime}, \mathrm{C}-3^{\prime}\end{array}$ \\
\hline $2^{a}$ & 161.0 & & \\
\hline 3 & 28.6 & $\begin{array}{l}3.20 \mathrm{dd}(15.5,7.8, \mathrm{Ha}) \\
3.26 \mathrm{dd}(15.5,9.4, \mathrm{Hb})\end{array}$ & $\begin{array}{l}\text { C-4, C-3a, } \\
\text { C-2a, C-2 }\end{array}$ \\
\hline $3^{a}$ & 109.4 & & \\
\hline 4 & 155.2 & & \\
\hline $4-\mathrm{OH}$ & & $14.31 \mathrm{~s}$ & $\mathrm{C}-4 \mathrm{a}, \mathrm{C}-4, \mathrm{C}-3 \mathrm{a}$ \\
\hline $4 \mathrm{a}$ & 108.4 & & \\
\hline 5 & 182.6 & & \\
\hline $5 \mathrm{a}$ & 125.4 & & \\
\hline 6 & 117.2 & $7.80 \mathrm{dd}(7.8,1.4)$ & C-8, C-9a, C-5 \\
\hline 7 & 120.4 & $7.15 \mathrm{t}(7.8)$ & C-9, C-5a \\
\hline 8 & 123.4 & $7.29 \mathrm{dd}(7.8,1.4)$ & C-9a, C-6 \\
\hline 9 & 148.8 & & \\
\hline $9^{\mathrm{a}}$ & 138.0 & & \\
\hline 11 & 126.6 & & \\
\hline $11^{\mathrm{a}}$ & 143.5 & & \\
\hline 1 ' & 71.5 & & \\
\hline $2^{\prime}$ & 26.1 & $1.33 \mathrm{~s}$ & $\mathrm{C}-2, \mathrm{C}-1^{\prime}, \mathrm{C}-3^{\prime}$ \\
\hline 3' & 27.5 & $1.29 \mathrm{~s}$ & $\mathrm{C}-2, \mathrm{C}-1^{\prime}, \mathrm{C}-2^{\prime \prime}$ \\
\hline $\mathrm{N}-\mathrm{CH}_{3}$ & 46.9 & $3.85 \mathrm{~s}$ & C-11a, C-9a \\
\hline $\mathrm{O}-\mathrm{CH}_{3}$ & 60.9 & $3.89 \mathrm{~s}$ & $\mathrm{C}-11$ \\
\hline
\end{tabular}

${ }^{\text {a }}$ Recorded at $100 \mathrm{MHz} ;{ }^{\text {b }}$ Recorded at $400 \mathrm{MHz}$.

Compound 3 was isolated as an amorphous powder, the molecular formula was determined as $\mathrm{C}_{20} \mathrm{H}_{21} \mathrm{NO}_{6}$ by HRESIMS, showing an $[\mathrm{M}+\mathrm{H}]^{+}$peak at $\mathrm{m} / \mathrm{z} 372.1447$.
The UV absorption band at $\lambda_{\max } 265,285,332$ and $410 \mathrm{~nm}$, IR absorptions at $v_{\max } 3509$ and $1620 \mathrm{~cm}^{-1}$ and comparison with ${ }^{1} \mathrm{H}$ and ${ }^{13} \mathrm{C}$ NMR data characterized an acridone nucleus. ${ }^{16-22}$ The lack of a characteristic signal of hydrogen-bonded hydroxy proton in the ${ }^{1} \mathrm{H}$ NMR spectrum, in acetone- $d_{6}$ and DMSO- $d_{6}$, and the shielded value of $\mathrm{C}-12$ at $\delta 177.7$ in the ${ }^{13} \mathrm{C}$ NMR spectrum suggested that there is no intramolecularly hydrogenbonded hydroxyl group as observed for $\mathbf{1}$ and $\mathbf{2}$. The ${ }^{1} \mathrm{H}$ NMR spectrum showed an ABX type aromatic spin system at $\delta 7.04(1 \mathrm{H}, \mathrm{t}, J 7.8 \mathrm{~Hz}, \mathrm{H}-10), 7.15(1 \mathrm{H}, \mathrm{dd}, J$ $7.8,1.5 \mathrm{~Hz}, \mathrm{H}-9)$ and $7.64(1 \mathrm{H}, \mathrm{dd}, J 7.8,1.5 \mathrm{~Hz}, \mathrm{H}-11)$. The spectrum also showed one $N$-methyl group at $\delta$ 3.65 and one $O$-methyl group at $\delta 3.77$. The presence of a 3-hydroxy-2,2-dimethyldihydropyran moiety was suggested by an oxymethine signal at $\delta 3.88(1 \mathrm{H}, \mathrm{m}$, $\mathrm{H}-3)$, two methylene protons $\mathrm{Ha}$ at $\delta 3.00(1 \mathrm{H}, \mathrm{dd}, J 16.8$, $5.7 \mathrm{~Hz}, \mathrm{Ha}-4), \mathrm{Hb} 2.61(1 \mathrm{H}, \mathrm{dd}, J 16.8,7.8 \mathrm{~Hz}, \mathrm{Hb}-4)$ and two methyl groups at $\delta 1.43\left(3 \mathrm{H}, \mathrm{s}, \mathrm{H}-1^{\prime}\right)$ and $1.28(3 \mathrm{H}, \mathrm{s}$, $\left.\mathrm{H}-2^{\prime}\right)$. The resonances at $\delta 69.1$ and 78.1 in the ${ }^{13} \mathrm{C}$ NMR spectrum supported the presence of this substituent on the acridone nucleus.

In the HMBC spectrum of $\mathbf{3}$, the methylene protons at $\delta 2.61(\mathrm{H}-4)$ showed correlations with C-4a $(\delta 103.9)$, C-5 ( $\delta$ 153.3), C-3 ( $\delta 69.1)$ and C-2 ( $\delta 78.1)$, indicating that the substituent was located at an angular position. This spectrum also showed the correlation of the $N$-methyl protons at $\delta 3.65$ with C-6a $(\delta 143.2)$ and $\mathrm{C}-7 \mathrm{a}(\delta 137.1)$. The $O$-methyl protons at $\delta 3.77$ showed correlation with C-6 at $\delta 130.4$; this value is consistent with an acridone having an $O$-methyl group in this position. ${ }^{17,23}$ Correlations of $\mathrm{H}-9, \mathrm{H}-10$ and $\mathrm{H}-11$ allowed the assignments of the carbons C-8, C-8a, C-9, C-10, $\mathrm{C}-11, \mathrm{C}-11 \mathrm{a}$ and C-12. Therefore, compound 3 was identified as 3,4-dihydro-3,5,8-trihydroxy-6-methoxy2,2,7-trimethyl-2H-pyrano[2,3-a]acridin-12(7H)one. Table 3 shows the data of ${ }^{1} \mathrm{H},{ }^{13} \mathrm{C}$ NMR and the correlation observed in the HMBC.

The eleven acridone alkaloids isolated from S. glutinosa were tested for in vitro activity against $P$. falciparum, $T$. b. rhodesiense and L. donovani. An assay with KB cells indicated in vitro cytotoxicity. The results are summarized in Table 4. To facilitate the discussion, $\mathrm{IC}_{50}$ values were assigned as $\mathrm{IC}_{50}^{\mathrm{T}, \mathrm{P}, \mathrm{K}}$ against $T$. b. rhodesiense, $P$. falciparum and $\mathrm{KB}$ cells, respectively.

Nine out of the eleven acridone alkaloids showed $\mathrm{IC}_{50}^{\mathrm{P}}$ below $10 \mu \mathrm{M}$, four showed $\mathrm{IC}_{50}^{\mathrm{T}}$ below $10 \mu \mathrm{M}$ and none displayed significant activity against $L$. donovani.

Related acridone alkaloids from Thamnosma rodesica (Bak. F.), showed activity against promastigote and amastigote forms of Leishmania major. These 
Table 3. ${ }^{1} \mathrm{H}$ and ${ }^{13} \mathrm{C}$ NMR and $\mathrm{HMBC}$ data for compound $\mathbf{3}$ (acetone- $d_{6}$ )

\begin{tabular}{|c|c|c|c|}
\hline position & ${ }^{13} \mathrm{C}^{\mathrm{a}} \delta$ & $\begin{array}{c}{ }^{1} \mathrm{H}^{\mathrm{b}} \delta \text { (mult., } \\
J \text { in } \mathrm{Hz} \text { ) }\end{array}$ & $\mathrm{HMBC}^{\mathrm{b}}(\mathrm{H}-\mathrm{C})$ \\
\hline $2^{\mathrm{a}}$ & $151,8^{*}$ & & \\
\hline 2 & 78.1 & & \\
\hline 3 & 69.1 & $3.88 \mathrm{~m}$ & \\
\hline 4 & 27.3 & $\begin{array}{l}3.00 \mathrm{dd}(16.8,5.7, \mathrm{Ha}) \\
2.61 \mathrm{dd}(16.8,7.8, \mathrm{Hb})\end{array}$ & $\mathrm{C}-3, \mathrm{C}-2, \mathrm{C}-1$ \\
\hline $4^{\mathrm{a}}$ & 103.9 & & \\
\hline 5 & $153.3^{*}$ & & \\
\hline 6 & 130.4 & & \\
\hline $6^{\mathrm{a}}$ & 143.2 & & \\
\hline 8 & 149.0 & & \\
\hline $7^{\mathrm{a}}$ & 137.1 & & \\
\hline 9 & 118.8 & $7.15 \mathrm{dd}(7.8,1.5)$ & $\mathrm{C}-7 \mathrm{a}, \mathrm{C}-11$ \\
\hline 10 & 123.1 & $7.04 \mathrm{t}(7.8)$ & C-8, C-11a \\
\hline 11 & 117.8 & $7.64 \mathrm{dd}(7.8,1.5)$ & $\mathrm{C}-7 \mathrm{a}, \mathrm{C}-9, \mathrm{C}-12$ \\
\hline $11 \mathrm{a}$ & 130.7 & & \\
\hline 12 & 177.7 & & \\
\hline $12 \mathrm{a}$ & 110.9 & & \\
\hline 1 ' & 20.5 & $1.43 \mathrm{~s}$ & $\mathrm{C}-3, \mathrm{C}-2, \mathrm{C}-2$, \\
\hline $2^{\prime}$ & 26.0 & $1.28 \mathrm{~s}$ & $\mathrm{C}-3, \mathrm{C}-2, \mathrm{C}-1$, \\
\hline $\mathrm{N}-\mathrm{CH}_{3}$ & 44.9 & $3.65 \mathrm{~s}$ & $C-4 a, C-5 a$ \\
\hline $\mathrm{O}-\mathrm{CH}_{3}$ & 59.7 & $3.77 \mathrm{~s}$ & $\mathrm{C}-4$ \\
\hline
\end{tabular}

${ }^{\text {a }}$ Recorded at $100 \mathrm{MHz} ;{ }^{\mathrm{b}}$ Recorded at $400 \mathrm{MHz} ; *$ Assignments may be exchanged. alkaloids have a methyl 2,3-dihydroxypropanoate chain at $\mathrm{C}-3$ and $\mathrm{C}-4,{ }^{23}$ indicating that the substitution in the acridone skeleton is important for activity in this class of compounds.

According to the data, compound $\mathbf{5}$, with one prenyl group at $\mathrm{C}-2$, was the most active against $P$. falciparum with $\mathrm{IC}_{50}^{\mathrm{P}} 0.3 \mu \mathrm{M}$. Comparison of $\mathbf{5 , 1}\left(\mathrm{IC}_{50}^{\mathrm{P}} 2.6 \mu \mathrm{M}\right)$ and $\mathbf{4}$ $\left(\mathrm{IC}_{50}^{\mathrm{P}} 2.6 \mu \mathrm{M}\right)$ indicates that the second prenyl at $\mathrm{C}-8$ was responsible for reducing the activity of this series. This fact was also observed by Weniger et al. ${ }^{10}$ who performed the assay with four alkaloids from $S$. glutinosa on a Nigerian chloroquine-sensitive strain of $P$. falciparum. Analysis of the results for compounds 2, 3, 9, 10 and $\mathbf{1 1}$ suggests that the presence of a pyran ring is important for activity against $P$. falciparum and the position of this group, angular pyrano[2,3-c] (9) or linear pyrano[3,2-b] (10), did not alter the results of $\mathrm{IC}_{50}^{\mathrm{P}}$.

The activity against $P$. falciparum observed for $\mathbf{6}$, 7 and $\mathbf{8}, \mathrm{IC}_{50}^{\mathrm{P}} 8.9,29.9$ and $6.1 \mu \mathrm{M}$, respectively, shows that presence of an $O$-methyl group at C-2 improves the activity.

From the 11 alkaloids tested against $T$. $b$. rhodesiense, compound 9 was the most active with an $\mathrm{IC}_{50}^{\mathrm{T}} 1.0 \mu \mathrm{M}$.

Alkaloids 1-3 had their citotoxicity to cancer cells described in an earlier paper, ${ }^{30}$ however here we disclose for the first time their isolation, spectral data and structure elucidation.

Table 4. In vitro activity against P. falciparum 3D7, T. b. rhodesiense STIB 900, L. donovani $\mathrm{L} 82$ and KB cells ${ }^{\mathrm{a}}$

\begin{tabular}{|c|c|c|c|c|}
\hline \multirow{2}{*}{ Compounds } & \multicolumn{3}{|c|}{$\mathrm{IC}_{50}$ in $\mu \mathrm{M}$} & \multirow[b]{2}{*}{ KB cell } \\
\hline & P. falciparum & T. b. rhodesiense & L. donovani & \\
\hline 1 & $2.6 \pm 0.4$ & $9.6 \pm 1.1$ & $>70$ & $19.8 \pm 3.7$ \\
\hline 2 & $3.0 \pm 0.2$ & $4.3 \pm 0.9$ & $>80$ & $>100$ \\
\hline 3 & $11.6 \pm 1.2$ & $28.5 \pm 2.9$ & $>80$ & $80.7 \pm 6.8$ \\
\hline 4 & $2.6 \pm 0.6$ & $14.4 \pm 1.8$ & $>76$ & $50.2 \pm 10.7$ \\
\hline 5 & $0.3 \pm 0.02$ & $12.0 \pm 0.8$ & $>70$ & $14.2 \pm 3.5$ \\
\hline 6 & $8.9 \pm 0.6$ & $7.8 \pm 2.6$ & $>76$ & $>100$ \\
\hline 7 & $29.9 \pm 2.1$ & $13.6 \pm 1.8$ & $>80$ & $84.9 \pm 12.8$ \\
\hline 8 & $6.1 \pm 1.8$ & $8.9 \pm 0.9$ & $>99$ & $>89.9$ \\
\hline 9 & $0.6 \pm 0.04$ & $1.0 \pm 0.1$ & $>56$ & $11.6 \pm 1.5$ \\
\hline 10 & $0.4 \pm 0.03$ & $17.0 \pm 1.9$ & $>35$ & $63.5 \pm 7.3$ \\
\hline 11 & $5.7 \pm 1.1$ & $21.7 \pm 5.3$ & $>46.4$ & $49.4 \pm 4.8$ \\
\hline chloroquine diphosphate ${ }^{\mathrm{b}}$ & $0.003 \pm 0.0002$ & & & \\
\hline pentamidine $^{\mathrm{c}}$ & & $0.035 \pm 0.0057$ & & \\
\hline pentostan $^{\mathrm{d}}$ & & & $15 \pm 3.4$ & \\
\hline podophyllotoxin ${ }^{\mathrm{e}}$ & & & & $0.0028 \pm 0.00005$ \\
\hline
\end{tabular}

${ }^{\mathrm{a}}$ The mean $\mathrm{IC}_{50}$ values of the test compounds and standard drug ( $n=3, \pm, \sigma, n=$ number of tests performed in three series). Drugs used as positive control: b ${ }^{\mathrm{b}}$ Plasmodium falciparum; ${ }^{\mathrm{c}} \mathrm{T}$. brucei rhodesiense; ${ }^{\mathrm{d}}$ Leishmania donovani and ${ }^{\mathrm{e}}$ toxicity. 


\section{Experimental}

General

Optical rotations were measured using a Perkin Elmer polarimeter. IR spectra were recorded on a Bomem M-B Series spectrophotometer. UV absorptions were recorded using a Varian 500 SCAN UV-Vis-NIR spectrophotometer. ${ }^{1} \mathrm{H}$ and ${ }^{13} \mathrm{C}$ NMR data were recorded on Bruker ARX-200 and Bruker DRX-400 spectrometers. Spectra were recorded in acetone- $d_{6}$ and DMSO- $d_{6}$ with TMS as internal standard. All 2D NMR data were recorded at 400MHz (Bruker DRX-400), HSQC J 145 Hz; HMBC $J 8 \mathrm{~Hz}$. HR-MS data were recorded on a Micromass Q-Tof (QqTOF) spectrometer; column chromatography was on silica gel 60 (Merck) and Sephadex LH-20 (Pharmacia). Preparative HPLC was performed on a Shodex Asahipak GS-310 2G column. TLC was carried out using Merck aluminum-backed silica gel $60 \mathrm{~F}_{254}$.

\section{Plant material}

Leaves, stem and root bark were collected in Campinas (SP) at the Instituto Agronômico de Campinas, and dried in the shade. The plant was identified by Prof. Dr. Maria Inês Salgado. A voucher specimen is deposited at the Herbarium of the Departamento de Botânica of the Universidade Federal de São Carlos (HUFSCar) as number 7110 .

\section{Extraction and isolation}

The parts of the plant were extracted separately with $n$-hexane at room temperature for 3 days, filtered and evaporated under reduced pressure at $40{ }^{\circ} \mathrm{C}$. This procedure was repeated 3 times to yield the crude hexane extract. The residue was extracted, as above, using $\mathrm{MeOH}$ to yield the crude $\mathrm{MeOH}$ extract. The crude $\mathrm{MeOH}$ extract $(60 \mathrm{~g})$ was fractioned by VCC over $1 \mathrm{~kg}$ of silica gel 60 (70-239 mesh, Merck) eluted with $1.5 \mathrm{~L}$ of the solvents: $100 \%$ hexane (fraction 1), $100 \% \mathrm{CH}_{2} \mathrm{Cl}_{2}$ (fraction 2), 3:1 $\mathrm{CH}_{2} \mathrm{Cl}_{2}: \mathrm{MeOH}$ (fraction 3); 2:1 $\mathrm{CH}_{2} \mathrm{Cl}_{2}: \mathrm{MeOH}$ (fraction 4); $1: 1 \mathrm{CH}_{2} \mathrm{Cl}_{2}: \mathrm{MeOH}$ (fraction 5) and $100 \% \mathrm{MeOH}$ (fraction 5). Fractions 2 and 3 were combined and chromatographed on silica gel using $\mathrm{CH}_{2} \mathrm{Cl}_{2}$ as mobile phase, the polarity was increased by addition of 5\%,10\%, 13\%, 18\%, 20\% and $25 \%$ of $\mathrm{MeOH}$ in a gradient system to yield 15 fractions. Lupeol was crystallized from fractions 1 to 3 . Fraction 5 was rechromatographed on Si gel, being eluted with 1:3 n-hexane-acetone followed by Sephadex LH-20 with $\mathrm{MeOH}$ to give alkaloids 1 (16.3 mg), 4 (30.4 mg),
5 (3.5 mg), 8 (11.2 mg), 9 (13.4 mg), 10 (9.8 mg) and 11 (5.4 mg). Further purification of fraction 9 on Sephadex LH-20 with $\mathrm{MeOH}$ and HPLC using $\mathrm{MeOH}$ as mobile phase, UV detection at 254 and $365 \mathrm{~nm}$, and a flow rate of $3.0 \mathrm{~mL} \mathrm{~min}^{-1}$ afforded compounds 6 (13.5 mg), 7 (11.2 mg) and 8 (7.3 mg). Fraction 10 was dissolved in $\mathrm{MeOH}$ and submitted to Sephadex LH-20, being eluted with $\mathrm{MeOH}$ to give compounds $2(5.2 \mathrm{mg})$ and $\mathbf{3}(4.3 \mathrm{mg})$.

1,3,5-Trihydroxy-4-methoxy-10-methyl-2,8-bis(3methylbut-2-enyl)acridin-9(10H)-one, (1)

Amorphous powder, IR (liquid film) $v_{\max } / \mathrm{cm}^{-1}: 3500$, 2964, 1625, 1566. UV (MeOH) $\lambda_{\max } / \mathrm{nm}(\log \varepsilon) 265$ (3.47), 285 (3.08), 332 (3.02) and $410(2.57) .{ }^{1} \mathrm{H},{ }^{13} \mathrm{C} \mathrm{NMR}$ and HMBC correlations see Table 1. HRESIMS m/z 424.2124 $[\mathrm{M}+\mathrm{H}]^{+}$(calc. for $\mathrm{C}_{25} \mathrm{H}_{30} \mathrm{NO}_{5}, 424.2124$ ).

2,3-Dihydro-4,9-dihydroxy-2-(2-hydroxypropan-2-yl)-11methoxy-10-methylfuro[3,2-b]acridin-5(10H)-one, (2)

Optically inactive, amorphous powder, IR (liquid film) $v_{\max } / \mathrm{cm}^{-1}: 3475,2964,1630$. UV $(\mathrm{MeOH}) \lambda_{\max } / \mathrm{nm}(\log$ ع): 259 (4.21), 274 (4.62), 284 (4.65). ${ }^{1} \mathrm{H},{ }^{13} \mathrm{C}$ NMR and HMBC correlations see Table 2. $\mathrm{m} / z$ 372.1447 $[\mathrm{M}+\mathrm{H}]^{+}$ (calc. for $\mathrm{C}_{20} \mathrm{H}_{22} \mathrm{NO}_{6}, 372.1447$ ).

3,4-Dihydro-3,5,8-trihydroxy-6-methoxy-2,2,7-trimethyl2H-pyrano[2,3-a]acridin-12 (7H)-one, (3)

$[\alpha]_{\mathrm{D}}^{25}-21.4(c, 0.0022 \mathrm{MeOH})$, amorphous powder, IR (liquid film) $v_{\max } / \mathrm{cm}^{-1}: 3509,2978,1620,1572$. UV (MeOH) $\lambda_{\text {max }} / \mathrm{nm}(\log \varepsilon): 264$ (3.39), 285 (3.13), 332 (2.99). ${ }^{1} \mathrm{H},{ }^{13} \mathrm{C}$ NMR and HMBC correlations see Table 3. HRESIMS $m / z 372.1447[\mathrm{M}+\mathrm{H}]^{+}$(calc. for $\mathrm{C}_{20} \mathrm{H}_{22} \mathrm{NO}_{6}$, 372.1447).

\section{Biological assays}

Stock solutions of the compounds, plus control drugs, were prepared at a concentration of $20 \mathrm{mg} \mathrm{mL}^{-1}$ in DMSO (Sigma, UK), and diluted to appropriate concentrations prior to assays. $\mathrm{IC}_{50}$ values were calculated with MSXLFIT (IDBS, UK).

\section{P. falciparum}

Chloroquine-sensitive $P$. falciparum strain 3D7 was maintained in human $\mathrm{A}^{+}$erythocytes in RPMI 1640 medium (Sigma, UK) supplemented with Albumax II at $37^{\circ} \mathrm{C}$ in a $5 \% \mathrm{CO}_{2}$-air mixture. Asynchronous (65-75\% ring stage) of $P$. falciparum intraerythrocytic cultures were set up as above, with $1 \%$ parasitemia, $2.5 \%$ hematocrit, in triplicate in $100 \mu \mathrm{L}$ of medium in 96 well, flat-bottomed Microtest III tissue plates. Drugs were added in a threefold dilution 
series and cultures incubated for a total of $48 \mathrm{~h}$ at $37^{\circ} \mathrm{C}$ in a $5 \% \mathrm{CO}_{2}$-air mixture. After $24 \mathrm{~h},\left\{{ }^{3} \mathrm{H}\right\}$ hypoxanthine $(0.2 \mathrm{mCi})$ was added to each well. ${ }^{25,26}$ At the end of the assay, plates were rapidly freeze-thawed, harvested using a Tomtec Mach III cell harvester (Tomtec, CT) onto a 96well format filtermat and Meltilex ${ }^{\mathrm{TM}}$ solid scintillant (both Wallac, Finland) added prior to reading in a Microbeta 1450 scintillation counter (Wallac, Finland) at 1 min per well.

\section{T. brucei rhodesiense}

T. b. rhodesiense STIB900 bloodstream form trypomastigotes were maintained in HMI-18 medium, ${ }^{27}$ with $15 \%$ heat-inactivated fetal calf serum (Harlan Sera Lab, UK) at $37{ }^{\circ} \mathrm{C}$ in a $5 \% \mathrm{CO}_{2}$-air mixture. Prior to drugging, trypomastigotes were washed and resuspended in fresh medium at a concentration $2 \times 10^{5}$ trypanosoma $/ \mathrm{mL}$ and $100 \mu \mathrm{L}$ of this suspension was added to the drug dilutions. The top concentration for the test compounds was $30 \mathrm{mg} \mathrm{mL}^{-1}$. Pentamidine was included as the standard drug. Plates were incubated for $72 \mathrm{~h}$ at $37^{\circ} \mathrm{C}$ in a $5 \% \mathrm{CO}_{2}^{-}$ air mixture. ${ }^{28}$ At $72 \mathrm{~h}$ AlamarBlue was added to the plates. Plates were read after 4-5 h on a Gemini fluorescent plate reader (Sofimax Pro. 3.1.1, Molecular Devices, UK) at EX/EM 530/585 nm with a filter cut-off at $550 \mathrm{~nm}$.

\section{L. donovani}

L. donovani L82 amastigotes were harvested from an infected hamster (Mesocricetus auratus) spleen and used to infect murine peritoneal exudate macrophages (PEM) at a ratio of $7: 1$. In brief, infected cells were exposed to drug for a total of 5 days. ${ }^{29}$ The percentage of infected cells was evaluated microscopically and the percentage inhibition in comparison with untreated controls was calculated.

\section{Cytotoxicity assays}

96-well plates were seeded with $\mathrm{KB}$ cells at $4 \times 10^{4} \mathrm{~mL}^{-1}$ (100 $\mu \mathrm{L}$ per well). Drugs at $300,30,3$ and $0.3 \mu \mathrm{g} \mathrm{mL} \mathrm{m}^{-1}$ were added in fresh overlay after $24 \mathrm{~h}$, in triplicate at each concentration. Plates were incubated for $72 \mathrm{~h}$ at $37^{\circ} \mathrm{C}$ in a $5 \% \mathrm{CO}_{2}$-air mixture. At $72 \mathrm{~h}$ AlamarBlue was added to the plates. Plates were read after $4-5 \mathrm{~h}$ on a Gemini fluorescent plate reader (Sofimax Pro. 3.1.1, Molecular Devices, UK) at EX/EM 530/585 nm with a filter cut-off at $550 \mathrm{~nm} . \mathrm{IC}_{50}$ values were calculated against the blanks and control samples.

\section{Acknowledgments}

The authors thank CNPq - Conselho Nacional de Desenvolvimento Científico e Tecnológico and Márcia
Ortiz Mayo Marques from the Instituto Agronômico de Campinas. Lauren Rattray and Simon Croft received support from UNDP/World Bank/WHO Research Programme for Tropical Diseases (TDR).

\section{Supplementary Information}

Available free of charge at http://jbcs.org.br, as PDF file.

\section{References}

1. Barrett, M. P.; Burchmore, R. J. S., Stich, A.; Lazzari J. O.; Frasch, A. C.; Cazzulo, J.; Krishnas, J.; Lancet 2003, 362, 1469.

2. Hoet, S.; Opperdoes, F.; Brun R.; Quetin-Leclercq, J. Q.; Nat. Prod. Rep. 2004, 21, 353.

3. Legros, D.; Ollivier, G.; Gastellu-Etchegory, M.; Paquet, C.; Burri, C.; Jannin, J.; Buscher, P.; Lancet Infect. Dis. 2002, 2, 437.

4. Wernsdorfer, W. H.; Acta Tropica 1994, 56, 143.

5. Sachs, J.; Malaney, P.; Nature 2002, 415, 680.

6. WHO; www.rbm.who.int, accessed in February 18, 2004.

7. Sundar, S.; Trop. Med. Int. Health 2001, 6, 849.

8. Croft, S. L.; Parasitology 1997, 114, S3.

9. Da Silva, M. F. G. F.; Gottlieb, O. R.; Ehrendorfer, F.; Pl. Syst. Evol. 1988, 161, 97.

10. Weniger, B.; Um, B-H.; Valentin, A.; Estrada, A.; Lobstein, A.; Anton, R.; Maillé, M.; Sauvain, M.; J. Nat. Prod. 2001, 64, 1221.

11. Yamamoto, N.; Furukawa, H.; Ito, Y.; Yoshida, S.; Maeno, K.; Nishiyama, Y.; Antiviral Res. 1989, 12, 21.

12. Kawaii, S.; Tomono, Y.; Katase, E.; Ogawa, K.; Yano, M.; Takemura, Y.; Motoharu, J.; Ito, C.; Furuhawa, H.; J. Nat. Prod. 1999, 62, 587.

13. Chaya, N.; Terauchi, K.; Yamagata, Y.; Kinjo, J.; Okabe, H.; Biol. Pharm. Bull. 2004, 27, 1312.

14. Wu, T-S.; Kuoh, C-S.; Furukawa, H.; Phytochemistry 1983, 22, 1493.

15. Ito, C.; Kondo, Y.; Wu, T-S.; Furukawa, H.; Chem. Pharm. Bull. 2000, 48, 65 .

16. Wu, T-S.; Furukawa, H.; Chem. Pharm. Bull. 1983, 31, 901.

17. Furukawa, H.; Yogo, M.; Wu, T-S.; Chem. Pharm. Bull. 1983, 31, 3084.

18. Wu, T-S.; Kuoh, C-S.; Furukawa, H.; Chem. Pharm. Bull. 1983, $31,895$.

19. Wu, T-S.; Furukawa, H.; Kuoh, C-S.; Hsu, K-S.; J. Chem. Soc., Perkin Trans. 1 1983, 1681.

20. Takemura, Y.; Wada, M.; Ju-ichi, M.; Ito, C., Furukawa, H.; Chem. Pharm. Bull. 1998, 46, 693.

21. Pegel, K. H.; Wright, W.G.; J. Chem. Soc. (C) 1969, 2327.

22. Fraser, A. W.; Lewis, J.R.; J. Chem. Soc., Perkin Trans. 1 1973, 1173. 
23. Wu, T-S.; Chen, C-M.; Chem. Pharm. Bull. 2000, 48, 85.

24. Ahua, K. M.; Ioset. J-R.; Ransijn, A.; Mauël, J.; Mavi, S.; Hostettmann, K.; Phytochemistry 2004, 65, 968.

25. Desjardins, R. E.; Canfield, C. J.; Haynes, J. D.; Chulay, J.D.; Antimicrob. Agents Chemother. 1979, 16, 710.

26. O’Neill, M. J.; Bray, D. H.; Boardman, P.; Phillipson, J. D.; Warhurst, D.C.; Planta Med. 1985, 61, 394.

27. Hirumi, H.; Hirumi, K.; J. Parasitol. 1989, 75, 985.

28. Räz, B.; Iten, M.; Grether-Buler, Y.; Kamisky, R.; Brun, R.; Acta Tropica 1997, 68, 139.
29. Neal, R.A.; Croft, S.L.; J. Antimicrob. Chemother. 1984, 14, 463.

30. Braga, P. A. C.; dos Santos, D. A. P.; da Silva, M. F. D. G. F.; Vieira, P. C.; Fernandes, J. B.; Houghton, P.J.; Fang, R.; Nat. Prod. Res. 2007, 21, 47.

Received: November 27, 2008

Web Release Date: April 3, 2009

FAPESP helped in meeting the publication costs of this article. 


\section{Antiparasitic Activities of Acridone Alkaloids from Swinglea glutinosa (Bl.) Merr.}

Djalma A. P. dos Santos, ${ }^{a}$ Paulo C. Vieira, ${ }^{*, a}$ M. Fátima das G. F. da Silva, ${ }^{a}$ João B. Fernandes, ${ }^{a}$ Lauren Rattray ${ }^{b}$ and Simon L. Croft ${ }^{b}$

${ }^{a}$ Departamento de Química, Universidade Federal de São Carlos, CP 676, 13565-905 São Carlos-SP, Brazil

${ }^{b}$ Department of Infectious and Tropical Diseases, London School of Hygiene \& Tropical Medicine, London, WC1E 7HT, UK

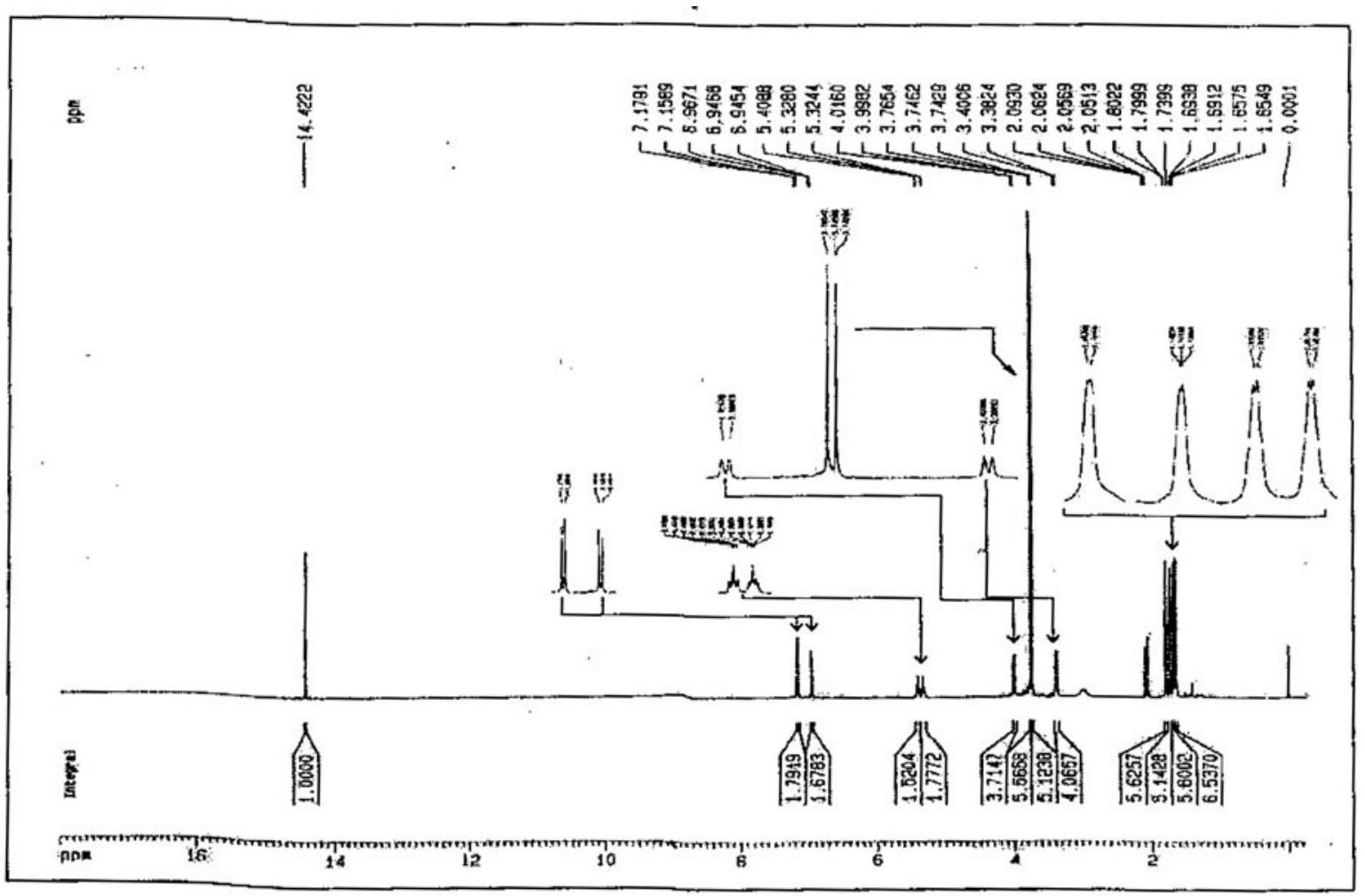

Figure S1. ${ }^{1} \mathrm{H}$ NMR spectrum of compound $\mathbf{1}\left(\mathrm{CDCl}_{3}, 400 \mathrm{MHz}\right)$. 


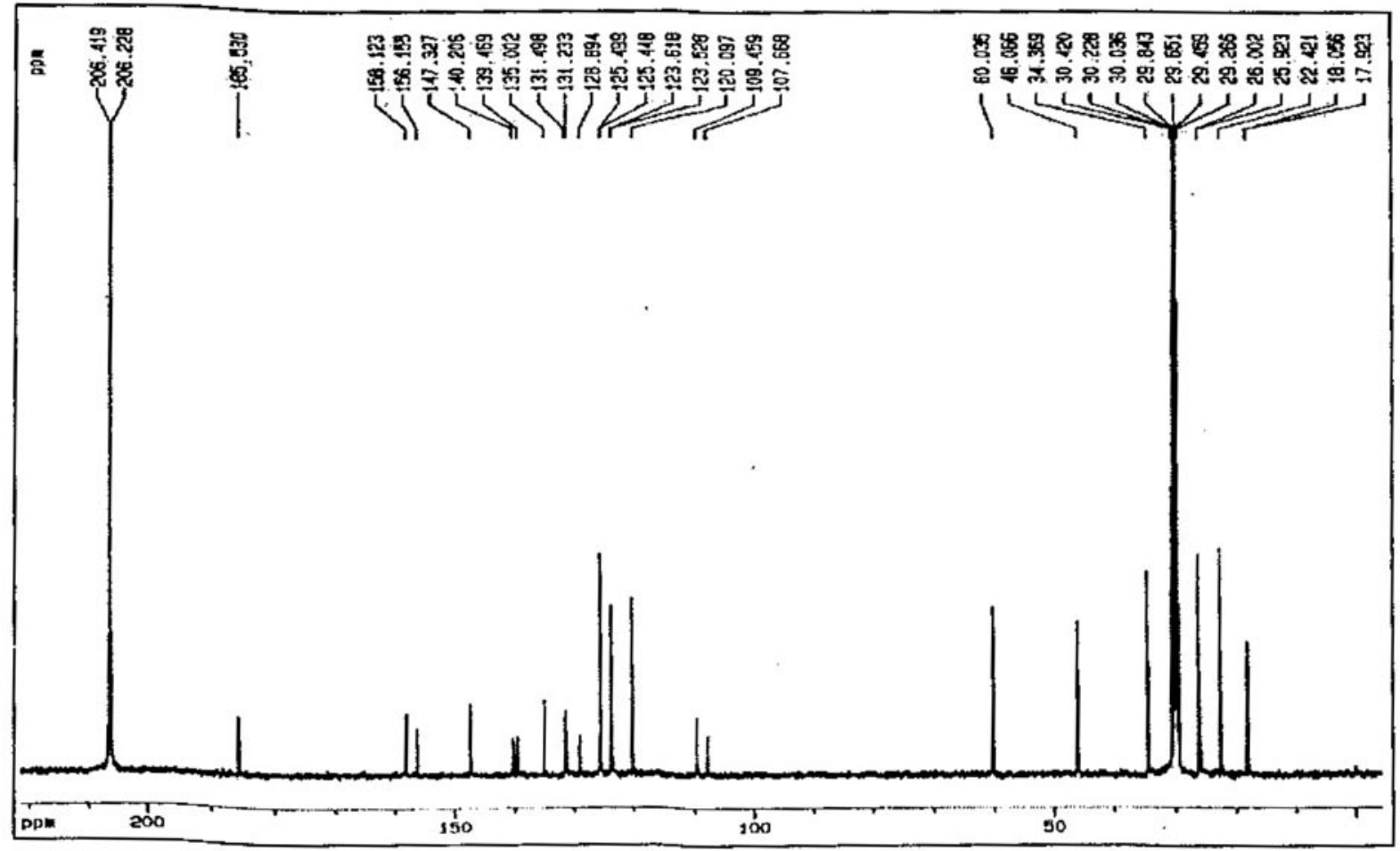

Figure S2. ${ }^{13} \mathrm{C}$ NMR spectrum of compound $\mathbf{1}\left(\mathrm{CDCl}_{3}, 100 \mathrm{MHz}\right)$.

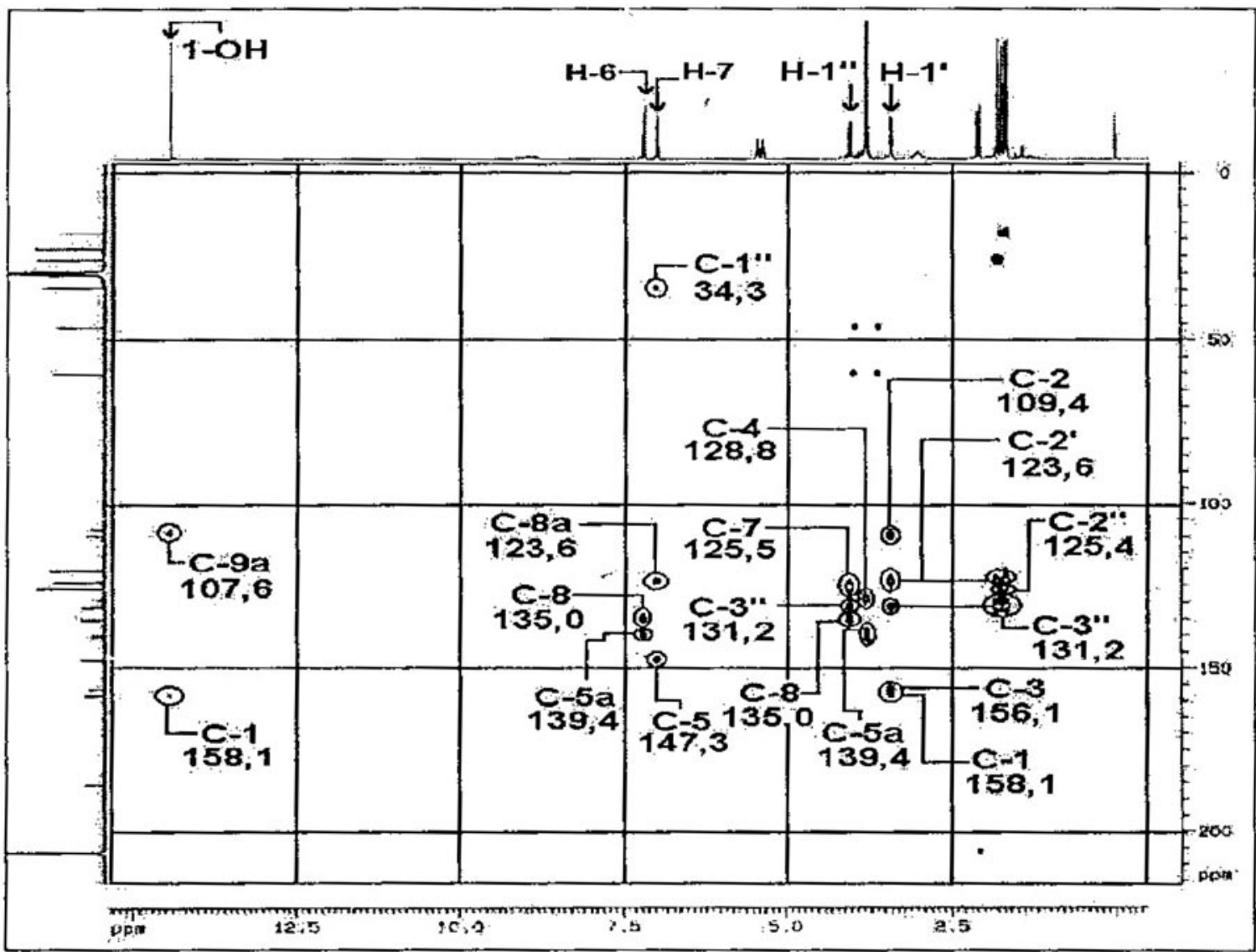

Figure S3. HMBC spectrum of compound d $\mathbf{1}\left(\mathrm{CDCl}_{3}\right)$ 


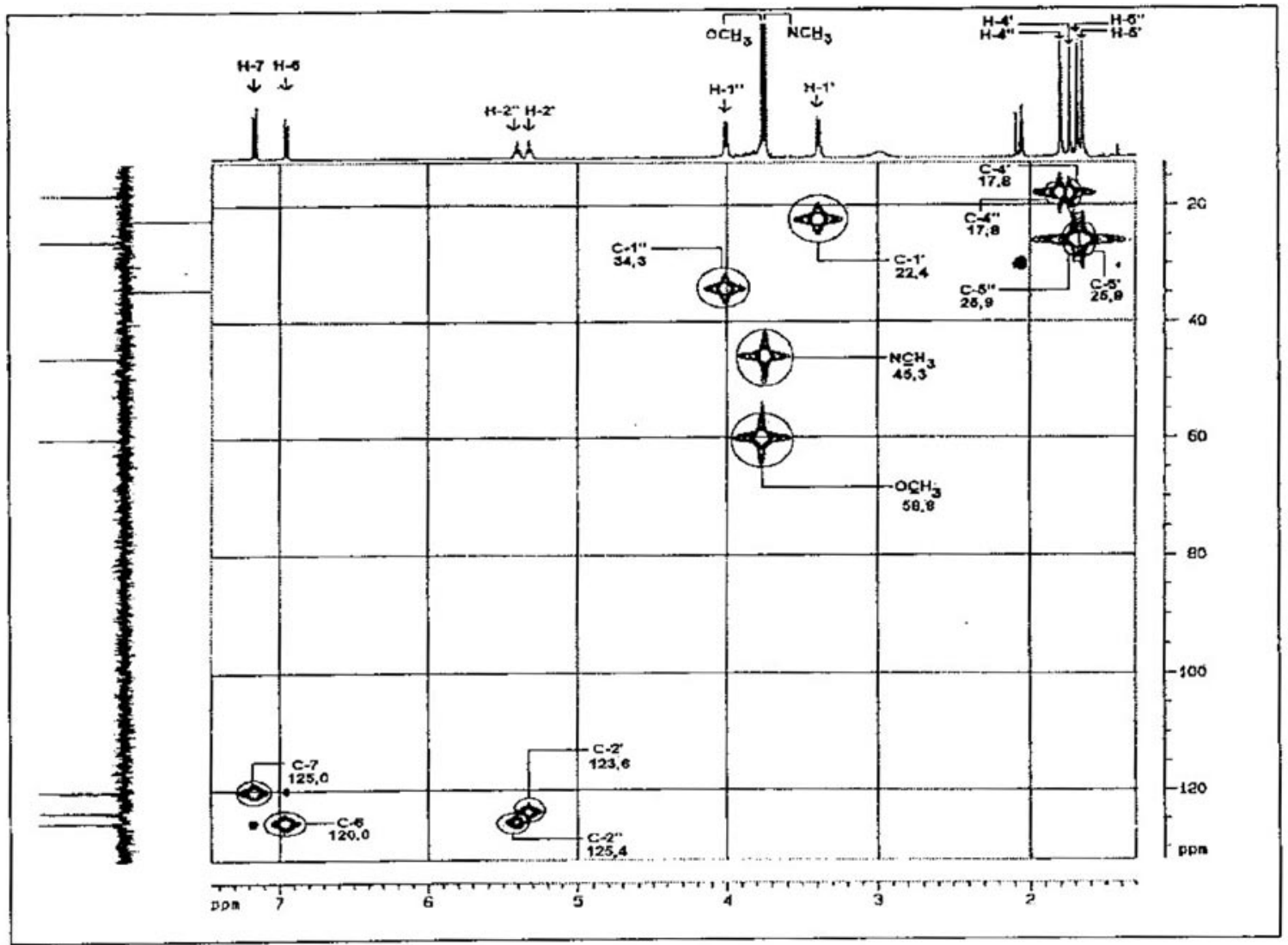

Figure S4. HMQC spectrum of compound $\mathbf{1}\left(\mathrm{CDCl}_{3}\right)$.

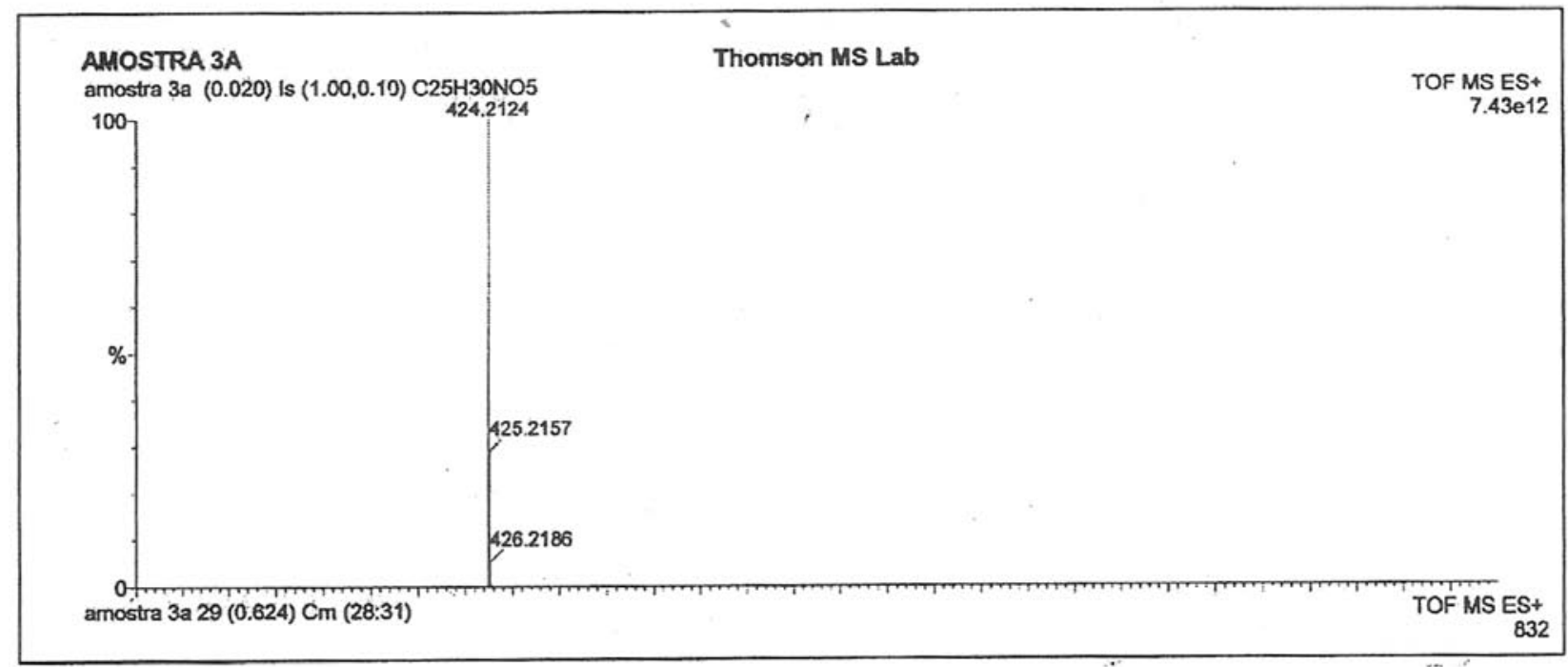

Figure S5. High resolution mass spectrum of compound 1. 


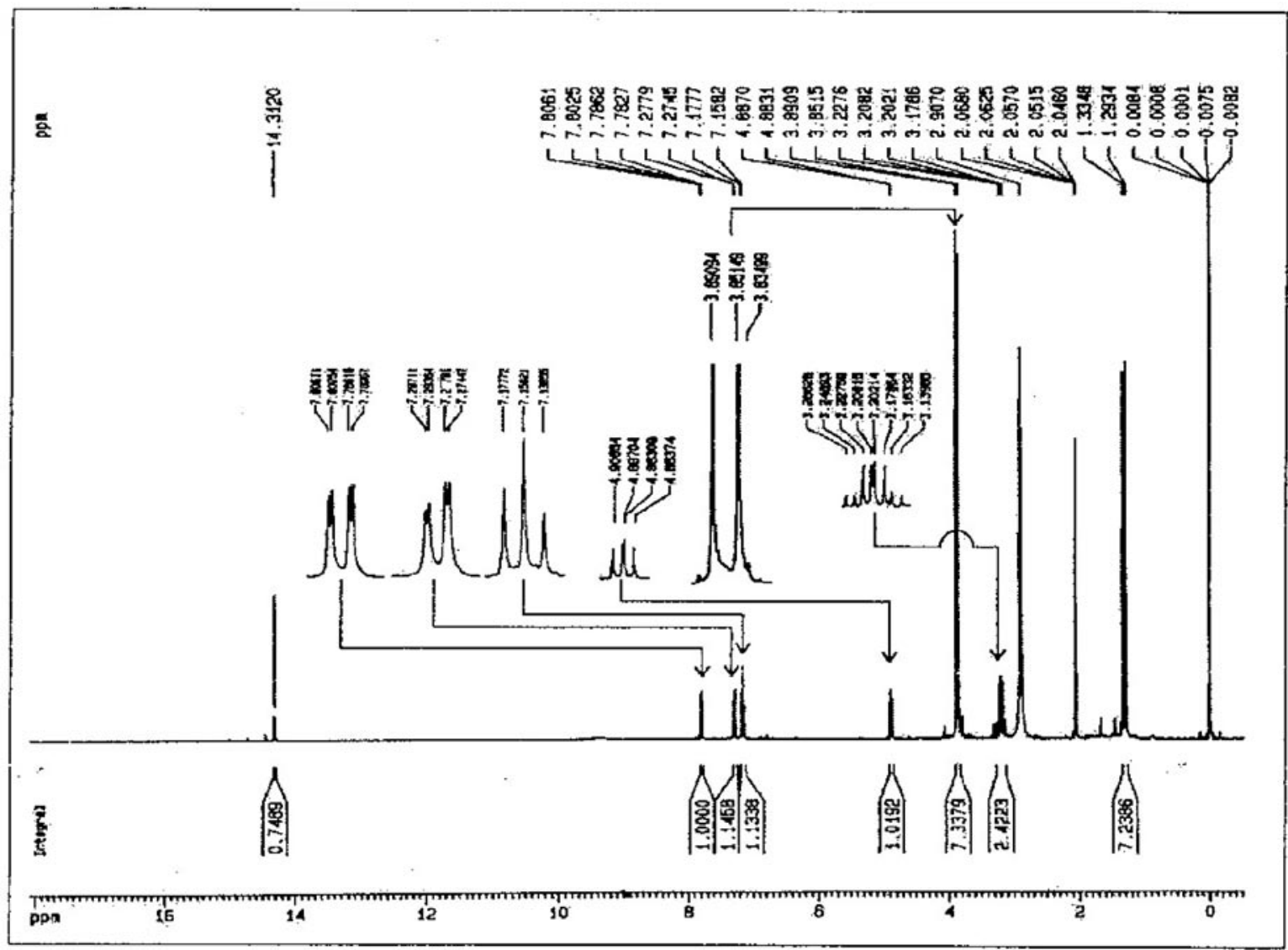

Figure S6. ${ }^{1} \mathrm{H}$ NMR of compound $2\left(\mathrm{CDCl}_{3}, 400 \mathrm{MHz}\right)$.

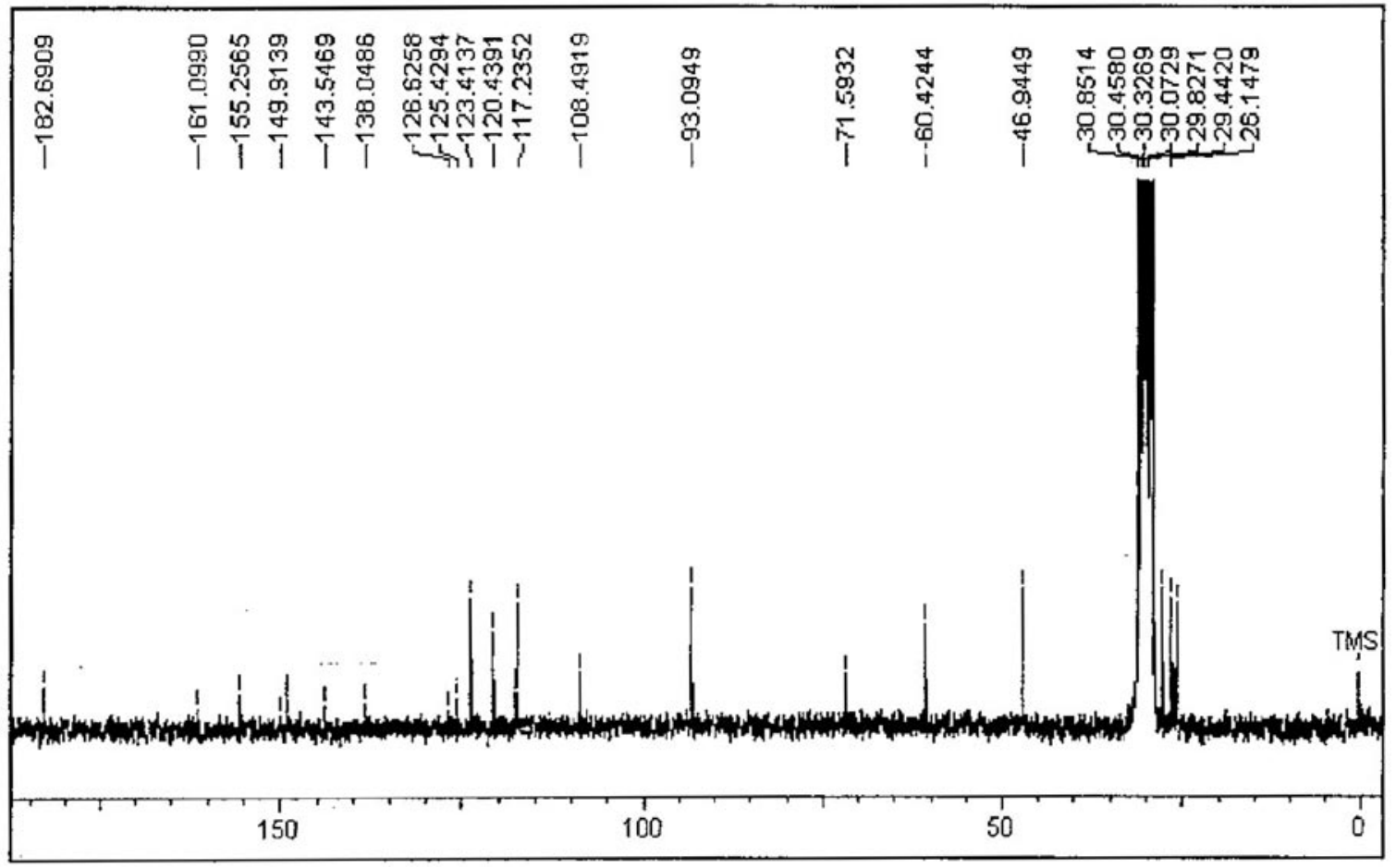

Figure S7. ${ }^{13} \mathrm{C}$ NMR of compound $2\left(\mathrm{CDCl}_{3}, 100 \mathrm{MHz}\right)$. 


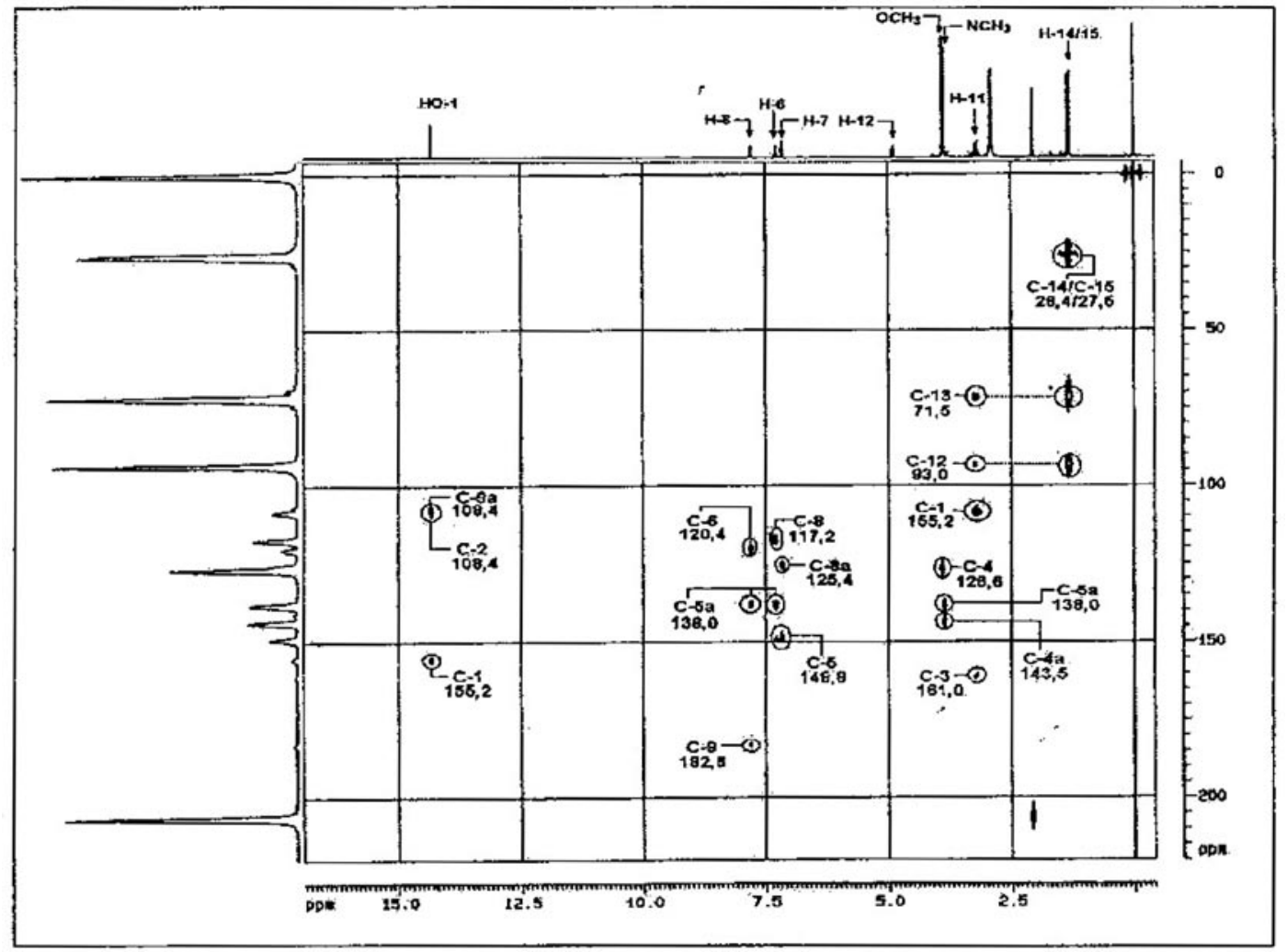

Figure S8. HMBC spectrum of compound $2\left(\mathrm{CDCl}_{3}\right)$.

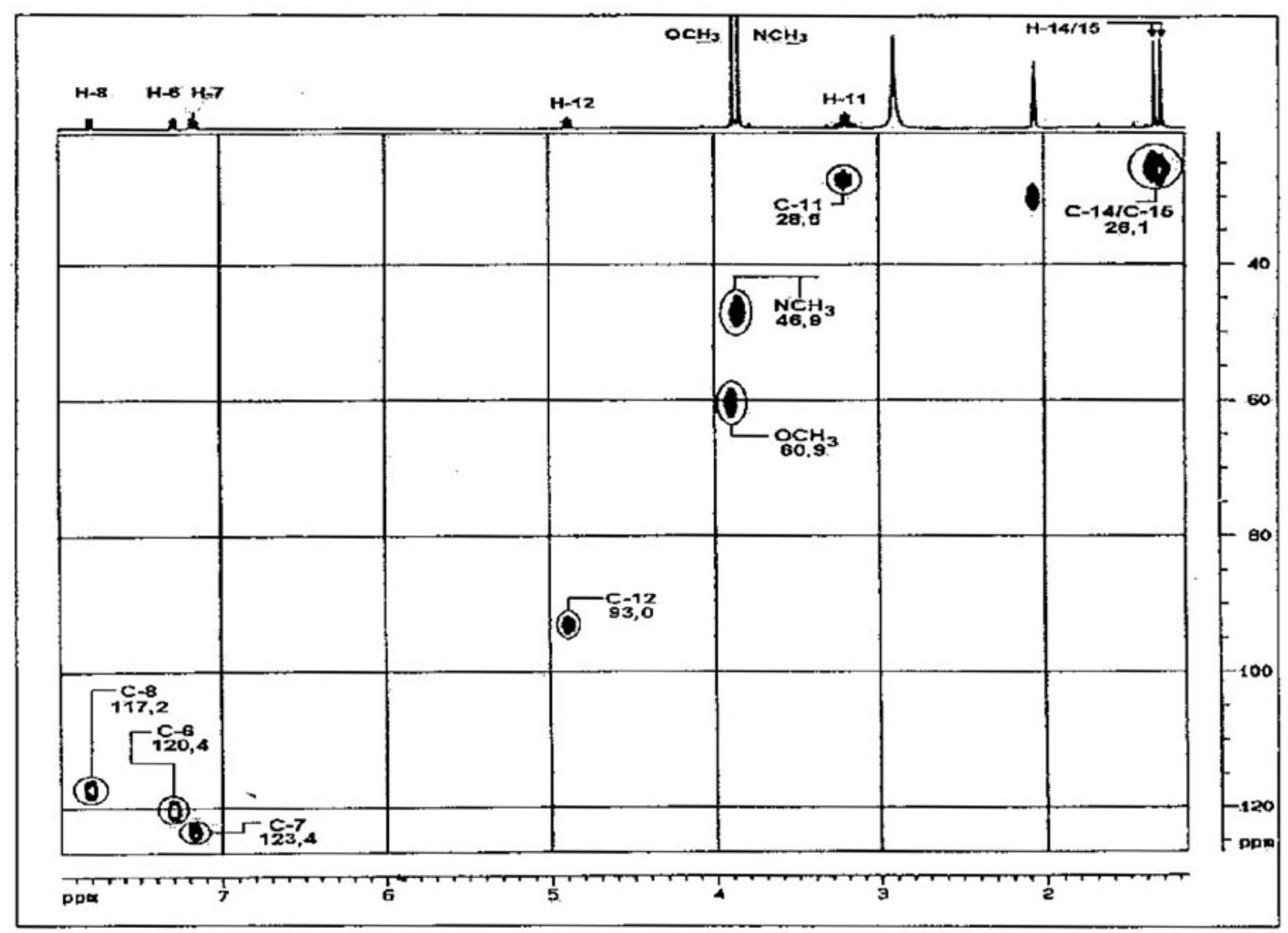

Figure S9. HMQC spectrum of compound $2\left(\mathrm{CDCl}_{3}\right)$. 


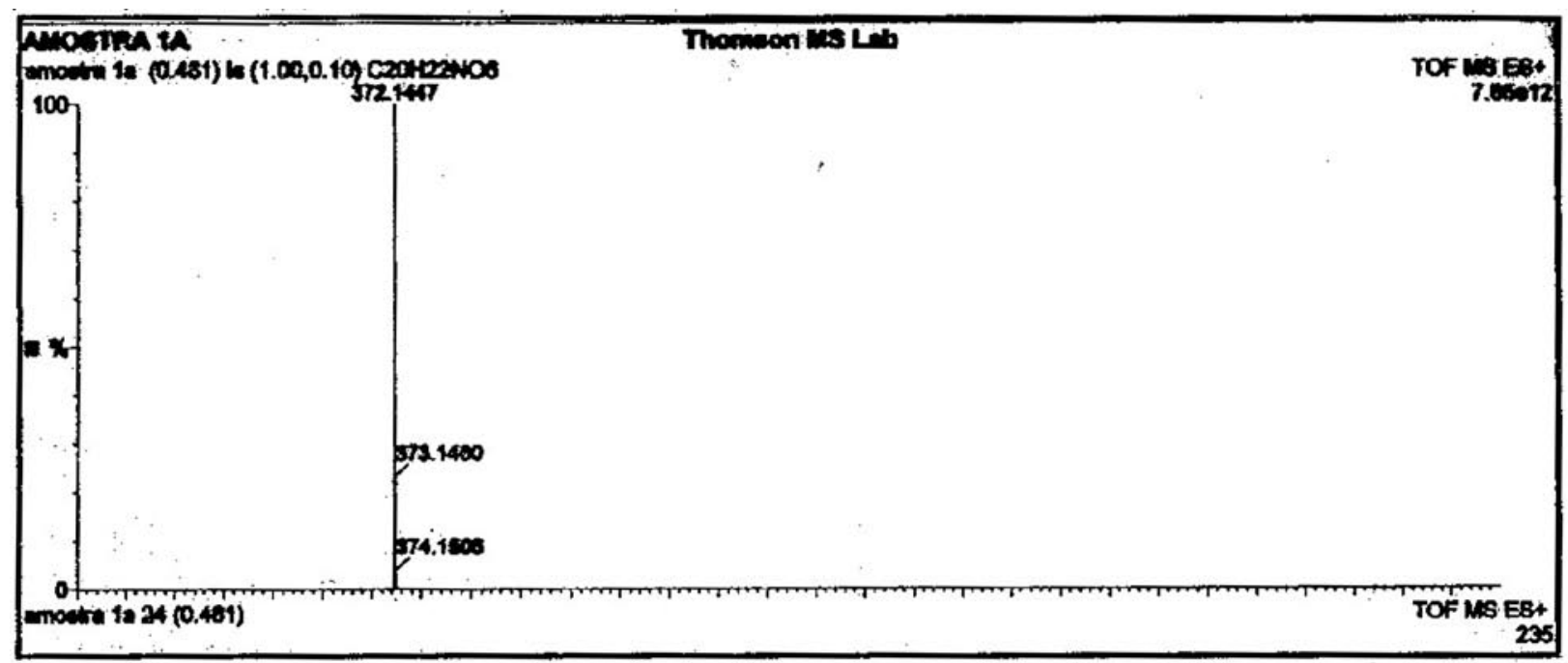

Figure S10. High resolution mass spectrum of compound 2.

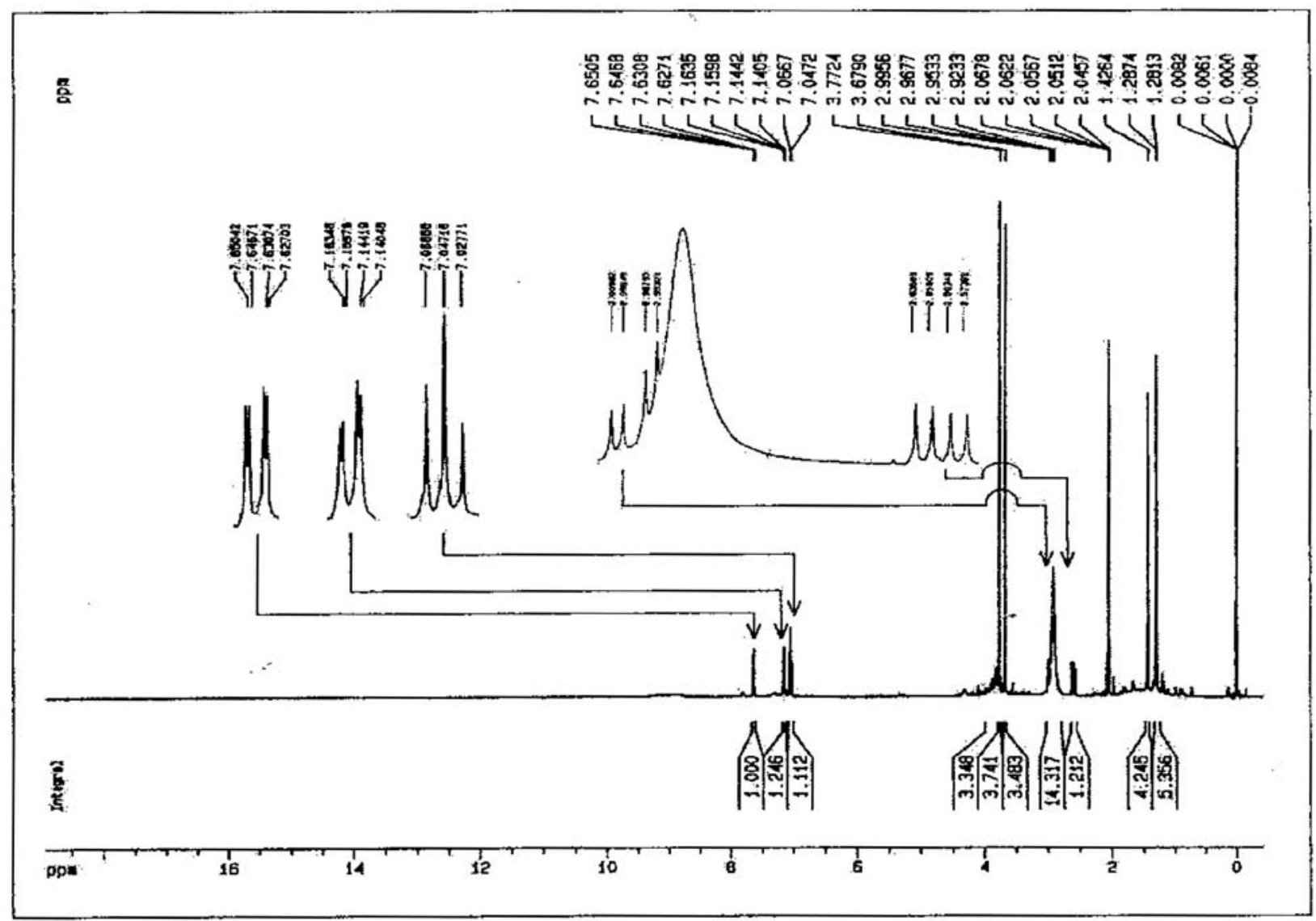

Figure S11. ${ }^{1} \mathrm{H}$ NMR of compound $\mathbf{3}\left(\mathrm{CDCl}_{3}, 400 \mathrm{MHz}\right)$. 


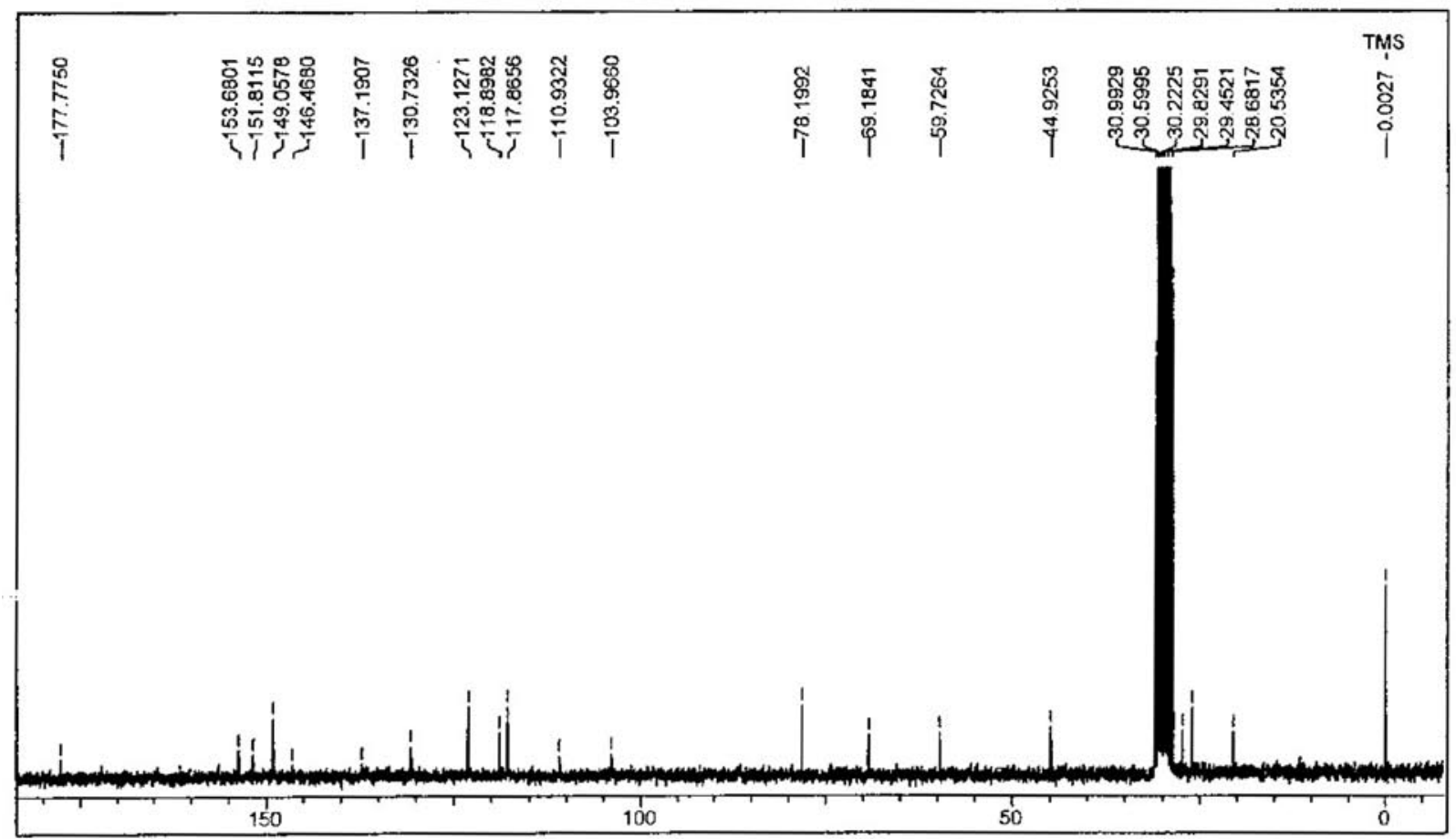

Figure S12. ${ }^{13} \mathrm{C}$ NMR of compound $\mathbf{3}\left(\mathrm{CDCl}_{3}, 100 \mathrm{MHz}\right)$.

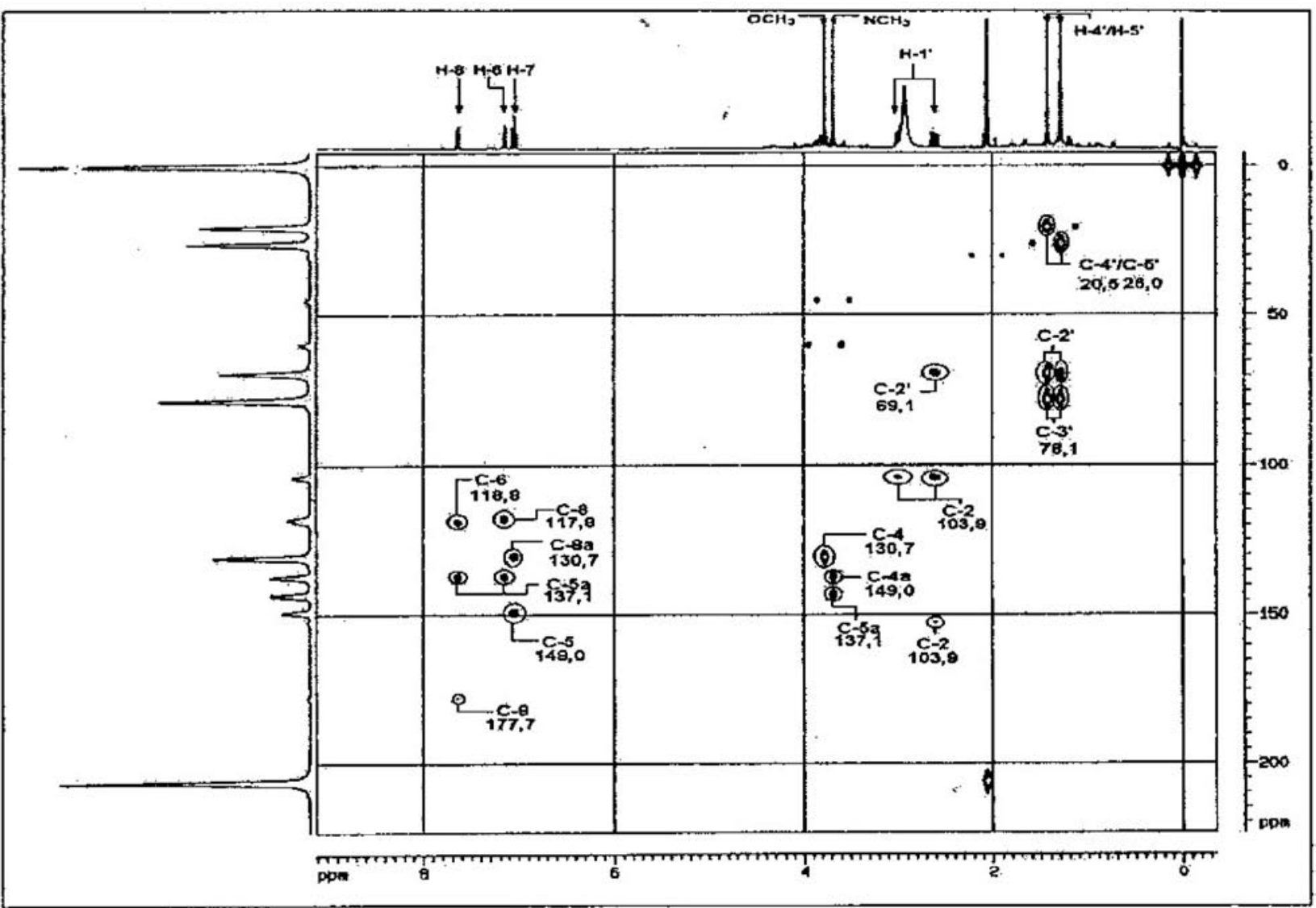

Figure S13. HMBC spectrum of compound $\mathbf{3}\left(\mathrm{CDCl}_{3}\right)$. 


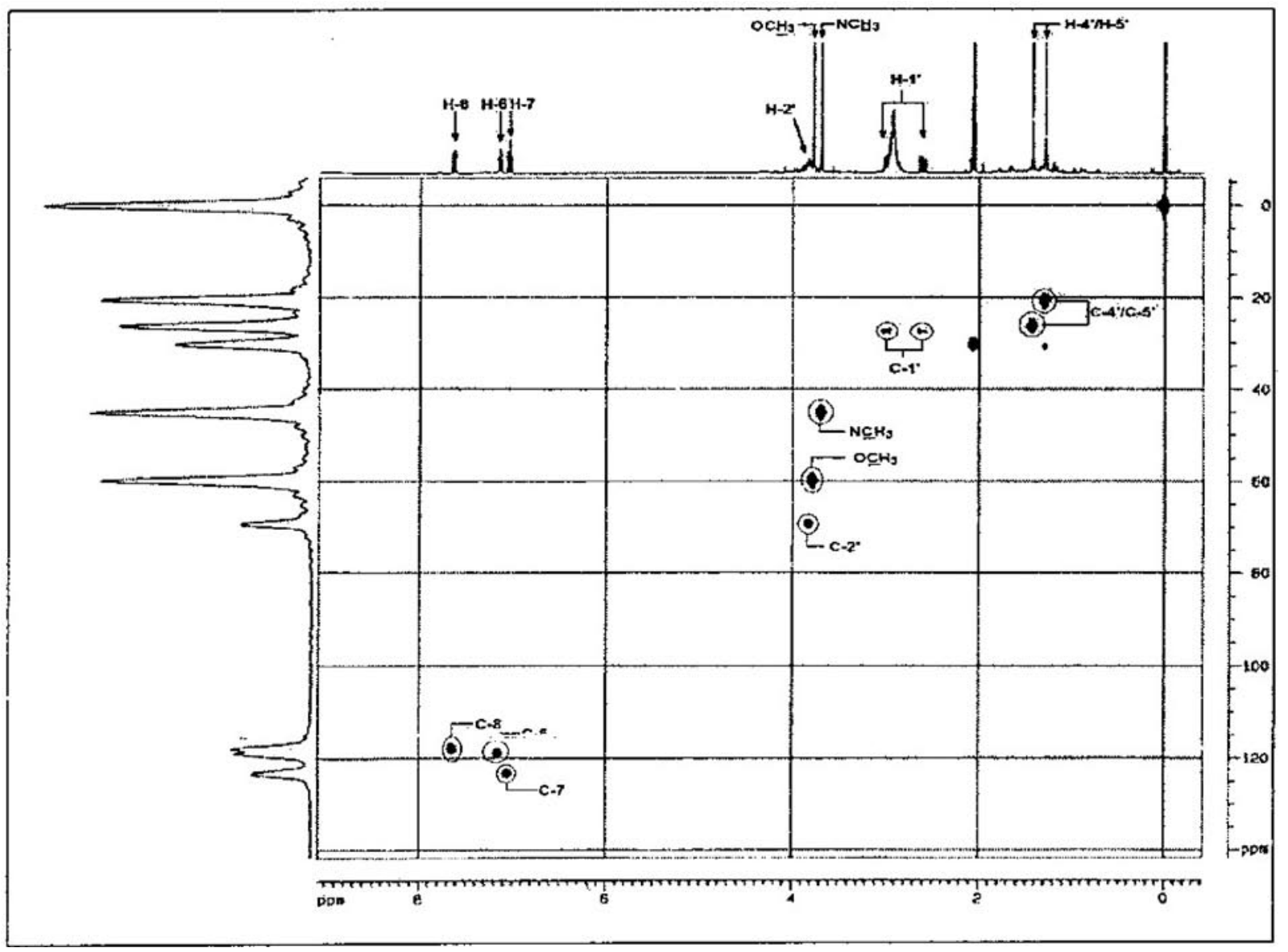

Figure S14. HMQC spectrum of compound $3\left(\mathrm{CDCl}_{3}\right)$.

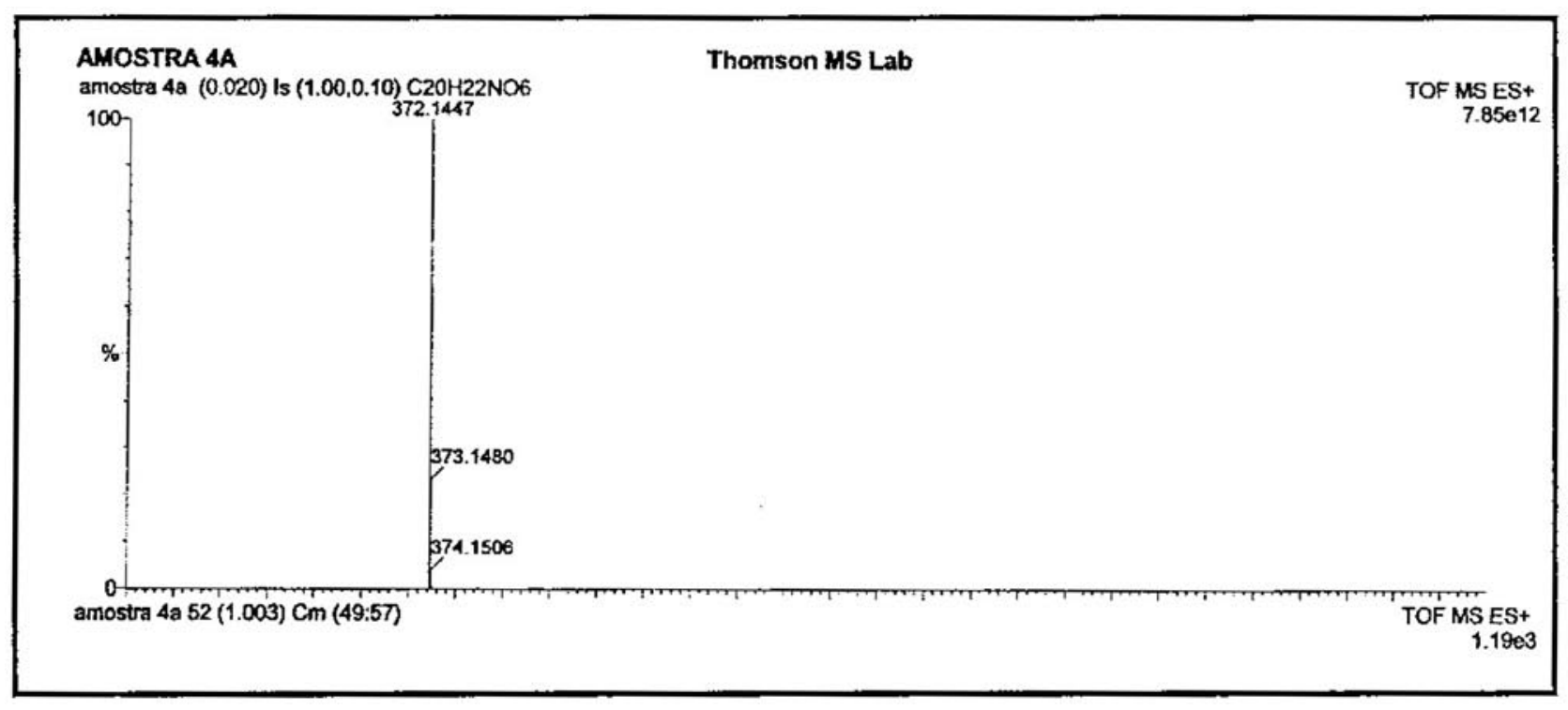

Figure S15. High resolution mass spectrum of compound 3. 